Article

\title{
Examining the Sustainability of Tropical Island Forests: Advances and Challenges in Measurement, Monitoring, and Reporting in the U.S. Caribbean and Pacific
}

\author{
Kathleen A. McGinley ${ }^{1, *}$, Guy C. Robertson ${ }^{2}$ and Kathleen S. Friday ${ }^{3}$ \\ 1 U.S. Department of Agriculture, Forest Service, International Institute of Tropical Forestry, \\ San Juan, PR 00926, USA \\ 2 U.S. Department of Agriculture, Forest Service, Washington Office, Washington, DC 20237, USA; \\ grobertson02@fs.fed.us \\ 3 U.S. Department of Agriculture, Forest Service, State and Private Forestry Region 5, Hilo, HI, 96720, USA; \\ kfriday@fs.fed.us \\ * Correspondence: kmcginley@fs.fed.us; Tel.: +1-919-600-3108
}

Received: 1 July 2019; Accepted: 12 October 2019; Published: 24 October 2019

\begin{abstract}
Forests across the U.S. and U.S. affiliated islands of the Caribbean and Pacific constitute rich and dynamic social-ecological systems that, while heterogeneous in many ways, share certain characteristics and trends that underscore the utility of sustainability assessments that go beyond single jurisdictional efforts. This paper summarizes a recent effort to assess the sustainability of tropical island forests of and politically affiliated with the U.S. using the Montréal Process criteria and indicator framework (MP C\&I), which address ecological, social, economic, and institutional dimensions of forests. Forests cover 45 percent of the total area and more than 50 percent of each island jurisdiction, except Hawaii (36 percent). Forest cover is generally stable over much of the area in terms of recent reference conditions. The history of human occupation and land alteration is a prominent determinant of current conditions throughout the islands, which exhibit relatively high rates of threatened species in comparison to mainland counterparts and particularly where endemism is high. The islands also harbor significant areas of new or novel assemblages of native and non-native forest species, predominately on abandoned agricultural lands cleared of native forests long ago, which have been shown to contribute to the restoration of these degraded lands and provide many other ecosystem services at levels as high as and in some cases higher than native forests. Although industrial-level commercial timber harvest is small to nonexistent on most islands, socioeconomic and cultural linkages to forests are extensive but difficult to quantify. Amassing a foundation of data sufficient to address the MP C\&I was challenging, in part due to the heterogeneity of the islands, island geography, and limited reporting capacities. We document significant improvements in the availability of data important for sustainability assessments in the last decade or so, especially with the extension of the U.S. Department of Agriculture Forest Service Forest Inventory and Analysis program to the islands. Likewise, we find the MP C\&I to be a useful tool for organizing and presenting information important for assessing forest sustainability. Nevertheless, considerable data gaps remain in the areas of biodiversity, forest functions and processes, and socioeconomic conditions of forests, which are critical elements to track across the islands, particularly in the context of climate change and ongoing anthropogenic pressures.
\end{abstract}

Keywords: forest sustainability; forest inventory; criteria and indicators; tropical forests; Hawaii; Pacific islands; Caribbean islands 


\section{Introduction}

More than a dozen island jurisdictions in the Caribbean and Pacific are politically affiliated with the United States, including the state of Hawaii, the territories of American Samoa, Guam, Puerto Rico, and the U.S. Virgin Islands, and the freely associated states of the Republic of the Marshall Islands, Federated States of Micronesia, Commonwealth of Northern Marianas, and Republic of Palau. These islands are rich in biological and cultural diversity, but they are faced with many challenges including reliance on imports for food and fuel security, limited supplies of fresh water, sea level rise, and increasingly unpredictable extreme weather events [1-6], some of which may be moderated or mitigated by the sustainable use and protection of forest ecosystems.

Forests span a wide range of life zones across the Caribbean and Pacific islands and harbor many rare and range-restricted or endemic species [7-9]. These forests are important socioeconomically, supporting local livelihoods and providing ecosystem services from local to global communities. Yet, they are subject to clearing and conversion to development, over-harvesting, introduction of non-native animal and plant species deemed invasive, and other anthropogenic and non-anthropogenic disturbances that have led to changes in forest cover and composition and are tied to high rates of species endangerment [1,10-13].

Understanding forest conditions and trends across ecological, economic, and social dimensions is of critical importance to sound policies and practices related to their use and conservation, and requires robust and reliable data across a broad spectrum of factors. However, consistent and comparable information on Caribbean and Pacific island forests as complex social-ecological systems is limited. Moreover, these islands often are overlooked or treated superficially in U.S. national-level forest sustainability and related analyses and reporting efforts, leaving local governments, federal partners, and other key actors with insufficient or partial information for forest-related policy- and decision-making. To address these knowledge gaps, we undertook a comprehensive sustainability assessment of ecological, economic, and social forest conditions and trends across nine Caribbean and Pacific island jurisdictions of and politically affiliated with the U.S. (Figure 1).

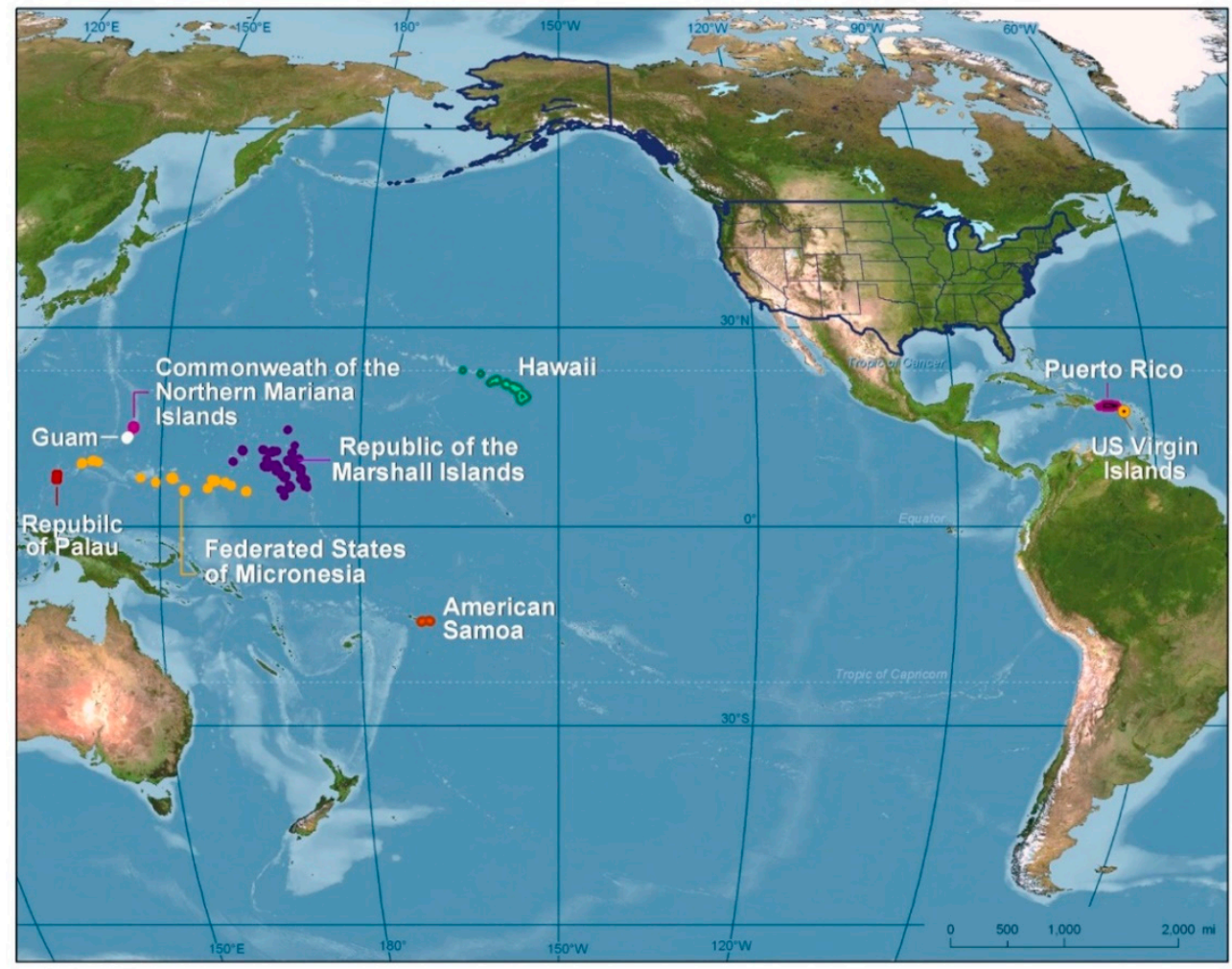

Figure 1. Location of the nine island jurisdictions encompassing the study area. 


\section{Criteria and Indicators of Forest Sustainability}

Measures of forest sustainability generally encompass ecological, economic, and social components and incorporate the ideals of intra- and inter- generational equity. These components can be delineated further into their specific parts and processes through criteria, which define the essential elements against which sustainability is assessed, and indicators, which are measurable parameters that correspond to a particular criterion $[14,15]$. Examining forest sustainability through criteria and indicators (C\&I) often involves a set of basic questions related to these component parts and processes. For instance, is forest area and structure being conserved? Are ecosystem functions and services being maintained? Is biodiversity being preserved? Are socioeconomic conditions improving? Are human institutions up to the task of sustainable forest management?

The immediate answers to these questions may indicate if and where more analysis is needed and, ultimately, where policy responses are required, which may necessitate new or increased levels of investment, cooperation, or other forms of intervention or adaptation in certain contexts, disturbance regimes, or tipping points. The answers to these questions and the associated responses also depend on the definition and assumptions associated with 'sustainability', which tend to evolve over time. Although there is ongoing debate at local to global levels on the definition, component parts, and bounds of 'forest sustainability' and the utility of associated evaluations and applications (see for example [16-19]), periodic assessments of forests through C\&I permit the tracking of conditions and trends across a comprehensive set of critical forest components and processes; the incorporation of new, emerging, or previously unmonitored aspects over time; and perhaps most importantly, the identification of parts or processes that shift beyond reference or otherwise collectively-agreed desired conditions [20-22].

We utilized the Montréal Process Criteria and Indicators for the Sustainable Management of Temperate and Boreal Forests (MP C\&I) as a framework for collecting, analyzing, and reporting information on the ecological, economic, and social dimensions of the islands' forests [23]. The MP C\&I is one of nine regional or forest-type frameworks developed over the past two to three decades through international initiatives to support forest sustainability measurement, monitoring, and reporting. These nine initiatives share many of the same or similar measures, integrating ecological with economic and social indicators towards a more holistic examination of forests as social-ecological systems [17,24]. While a tropics-oriented C\&I framework may seem more fitting for this study, the MP C\&I framework has several advantages in this particular application (in addition to the fact that most of the MP indicators are similar to those in the various other frameworks currently in use): (1) the MP C\&I have been in use by twelve member countries for over twenty years and revised over time based on experience from their application, such that the current indicator set has been vetted internationally; (2) it is designed for flexible application across different countries and settings; and (3) it aligns with ongoing U.S. temperate forest sustainability assessment and reporting activities, permitting increased integration and visibility of island forest conditions and trends in future national level efforts [25].

The MP C\&I are comprised of fifty-four indicators arranged under seven overarching criteria (Table 1). The first five criteria and twenty-four associated indicators address biophysical forest characteristics. The sixth criterion encompasses twenty indicators that address the social and economic aspects of forests. The seventh criterion and its ten indicators address laws, policies, and other institutional factors associated with forests and their management.

In the sections that follow, we provide an overview of the nine island jurisdictions included in this study, followed by a brief description of the methods we used for this assessment. Then, we present forest conditions and trends within and across jurisdictions organized by MP criterion. Finally, we discuss the overarching key findings from our assessment and reflect on the advances and limitations of forest sustainability assessments in tropical island settings, considering theoretical as well as practical implications. 
Table 1. Montreal Process Criteria and Indicators criterion level summary.

\begin{tabular}{ll}
\hline Criterion Name & Description \\
\hline 1. Conservation of biological diversity & $\begin{array}{l}\text { Nine indicators describing the biophysical characteristics of forests, } \\
\text { including forest extent, composition, diversity of flora and fauna. } \\
\text { Conservation efforts also covered }\end{array}$ \\
\hline $\begin{array}{l}\text { 2. Maintenance of productive capacity } \\
\text { of forest ecosystems }\end{array}$ & $\begin{array}{l}\text { Five indicators describing forest productive capacity, area of planted } \\
\text { forests, and current production levels of forest outputs (timber and } \\
\text { nontimber) }\end{array}$ \\
\hline $\begin{array}{l}\text { 3. Maintenance of forest ecosystem } \\
\text { health and vitality }\end{array}$ & $\begin{array}{l}\text { Two indicators describing (1) biotic forest disturbance processes } \\
\text { (e.g., insects and diseases); and (2) abiotic disturbance processes } \\
\text { (e.g., fire and drought) }\end{array}$ \\
\hline $\begin{array}{l}\text { 4. Conservation and maintenance of } \\
\text { soil and water resources }\end{array}$ & $\begin{array}{l}\text { Five indicators describing forest soils and water conditions along with } \\
\text { efforts to conserve them }\end{array}$ \\
\hline $\begin{array}{l}\text { 5. Maintenance of forest contribution } \\
\text { to global carbon cycles }\end{array}$ & $\begin{array}{l}\text { Three indicators describing (1) forest carbon pools; (2) carbon pools in } \\
\text { long-lived forest products; and (3) avoided carbon emissions from } \\
\text { using wood to produce energy }\end{array}$ \\
\hline $\begin{array}{l}\text { 6. Maintenance and enhancement of } \\
\text { long-term multiple socioeconomic } \\
\text { benefits to meet the needs of societies }\end{array}$ & $\begin{array}{l}\text { Twenty indicators describing (1) the production and consumption of } \\
\text { forest products; (2) investments in the forest sector and related human } \\
\text { capital; (3) forest employment and community conditions; (5) } \\
\text { forest-based recreation and tourism activity; and (5) cultural and } \\
\text { spiritual values associated with forests }\end{array}$ \\
\hline $\begin{array}{l}\text { 7. Legal, institutional and economic } \\
\text { framework for forest conservation and } \\
\text { sustainable management }\end{array}$ & $\begin{array}{l}\text { Ten indicators describing legal, economic, and other institutional } \\
\text { arrangements for forest planning and management, public } \\
\text { participation mechanisms, economic incentives and monitoring efforts }\end{array}$ \\
\hline & \multicolumn{1}{c}{ Source: [23,25]. }
\end{tabular}

\section{Study Area}

Nine tropical island jurisdictions having political associations with the U.S. federal government ranging from statehood (Hawaii) to the freely associated nations of Micronesia and Palau were included in this study (Table 2). These jurisdictions stretch across more than 16,000 $\mathrm{km}$ from the U.S. Virgin Islands, at the eastern most point, to the Republic of Palau, at the western most point (Figure 1). They span a considerable swath of longitude and latitude within the tropical belt and are subject to the many influences of island biogeography $[26,27]$. The group includes comparatively larger islands with mountain ranges exceeding $4000 \mathrm{~m}$ above sea level (masl) in the Pacific (i.e., Hawaii) and exceeding 1000 masl in the Caribbean (i.e., Puerto Rico) to relatively small, low lying, widely dispersed islands and atolls that do not exceed 10 masl (e.g., the Marshall Islands). Social-ecological characteristics and conditions vary across the islands, in relation to divergent geographies and histories of human settlement and use.

Table 2. Characteristics of the nine island jurisdictions in the study area (listed from east to west).

\begin{tabular}{|c|c|c|c|c|c|}
\hline \multirow{2}{*}{ Island Jurisdictions } & \multirow{2}{*}{$\begin{array}{l}\text { Total Area } \\
\left(\mathrm{km}^{2}\right)\end{array}$} & \multirow{2}{*}{ Political Status } & \multicolumn{2}{|c|}{ Islands and Atolls } & \multirow{2}{*}{$\begin{array}{l}\text { Population } \\
\text { (2018) }\end{array}$} \\
\hline & & & $\begin{array}{l}\text { Permanently } \\
\text { Inhabited }\end{array}$ & Other & \\
\hline \multicolumn{6}{|l|}{ Caribbean } \\
\hline U.S. Virgin Islands & 346 & Territory & 4 & $\sim 50$ & 106,977 \\
\hline $\begin{array}{c}\text { Puerto Rico } \\
\text { Pacific }\end{array}$ & 8870 & Commonwealth & 3 & $\sim 143$ & $3,195,153$ \\
\hline Hawaii & 16,635 & State & 7 & $\sim 140$ & $1,420,491$ \\
\hline American Samoa & 199 & Territory & 6 & 1 & 50,826 \\
\hline Guam & 544 & Territory & 1 & & 167,772 \\
\hline
\end{tabular}


Table 2. Cont.

\begin{tabular}{|c|c|c|c|c|c|}
\hline \multirow{2}{*}{ Island Jurisdictions } & \multirow{2}{*}{$\begin{array}{c}\text { Total Area } \\
\left(\mathbf{k m}^{2}\right)\end{array}$} & \multirow[b]{2}{*}{ Political Status } & \multicolumn{2}{|c|}{ Islands and Atolls } & \multirow{2}{*}{$\begin{array}{l}\text { Population } \\
\text { (2018) }\end{array}$} \\
\hline & & & $\begin{array}{l}\text { Permanently } \\
\text { Inhabited }\end{array}$ & Other & \\
\hline $\begin{array}{l}\text { Republic of the } \\
\text { Marshall Islands }\end{array}$ & 181 & Nation & 24 & 10 & 75,684 \\
\hline $\begin{array}{c}\text { Federated States } \\
\text { of Micronesia }\end{array}$ & 702 & Nation with four states & $\sim 77$ & 542 & 103,643 \\
\hline $\begin{array}{l}\text { Commonwealth of the } \\
\text { Northern Marianas }\end{array}$ & 464 & Commonwealth & 3 & 12 & 51,994 \\
\hline Republic of Palau & 459 & Nation with 16 states & 8 & 250 & 21,516 \\
\hline
\end{tabular}

\section{Methods}

Criteria and indicator frameworks for resource measurement, monitoring, and reporting generally require or rely on established data sources and streams to populate indicators with information on conditions and trends. In our application of the MP C\&I, first we identified available data sources for each criterion and its associated indicators at the jurisdiction level. We also identified related reporting activities from which we could draw relevant and related data. Some regularly collected data were available for a limited number of indicators, mostly related to biophysical elements and basic human demographics, but many of the indicators relied on one-time studies, proximal data, and/or anecdotal information.

Once available data streams and other relevant information were identified, we assembled and analyzed the data within and across criteria and island jurisdictions, combining indicators where data were limited or adjusting indicator focus to fit the island setting. We then analyzed the similarities and differences at different scales within the MP C\&I framework and within and across the nine island jurisdictions. This analysis, however, did not include testing of all or specific indicators against sustainability thresholds-rather, we used the MP C\&I to organize and present information on forests in a synthetic fashion.

Social-ecological heterogeneity across and within island jurisdictions is one of the study's most salient aspects and presented considerable challenges for a comprehensive assessment of forest sustainability for the region as a whole. Nevertheless, assessing the islands side-by-side, regionally, and altogether permitted the identification of similarities and distinctions in terms of their ecological, economic, and social conditions and trends, as well as opportunities and red flags to be carefully considered when contemplating their sustainability and related policies and practices. (Detailed data collection and analysis methods at criterion level are described further in McGinley et al. [23]).

\section{Results}

In the sections that follow, we present key results by Montreal Process criterion at aggregate, regional, jurisdictional, and sub-jurisdictional levels, where available. We also discuss the availability and adequacy of data for reporting on forest sustainability at the criterion level.

\subsection{Conservation of Biological Diversity: MP Criterion 1}

Criterion 1 focuses on the biological diversity of forests at ecosystem, species, and genetic levels, as well as related forest conditions and conservation efforts. We identified fairly extensive and reliable data on forest cover and ecosystem diversity for all island jurisdictions, and more modest levels of data on forest ownership, protection, species and genetic diversity, and risk of extinction for most jurisdictions.

Forests cover 1.285 million hectares of the nine island jurisdictions (i.e., 45.4 percent of total area) and encompass more than 25 forested life zones [30-34]. (The Holdridge Life Zone system empirically 
defines the conditions for vegetation growth based on bioclimatic information (e.g., biotemperature, precipitation, and evapotransipiration) [35]. Vegetative community classes have not been fully developed for all of the islands and those that do exist have not been standardized across the islands or similar life zones. Therefore, we examined the islands' forests according to the Holdridge Life Zones system, which can be used as a proxy for ecosystem or community type). Most of these islands were nearly completely to entirely forested prior to human occupation and many underwent some or, in many cases, a significant degree of forest conversion to agricultural and grazing lands, or to grasslands and badlands [36,37]. These land use changes occurred during periods of initial settlement, colonization, agricultural expansion, and related population growth, primarily on relatively accessible islands and those with more gently sloped terrain (e.g., the larger islands of Hawaii and Puerto Rico) [36-41]. Far less deforestation or conversion to other land uses, if any, occurred on the most isolated islands (e.g., those of Palau) or on those with forests on steep, rugged terrain and in very wet climates (e.g., Tutuila in American Samoa, high islands in eastern Micronesia). Today, forest cover ranges from 36 percent in Hawaii to 89 percent in Palau and all island jurisdictions but Hawaii are more than 50 percent forested (Figure 2).

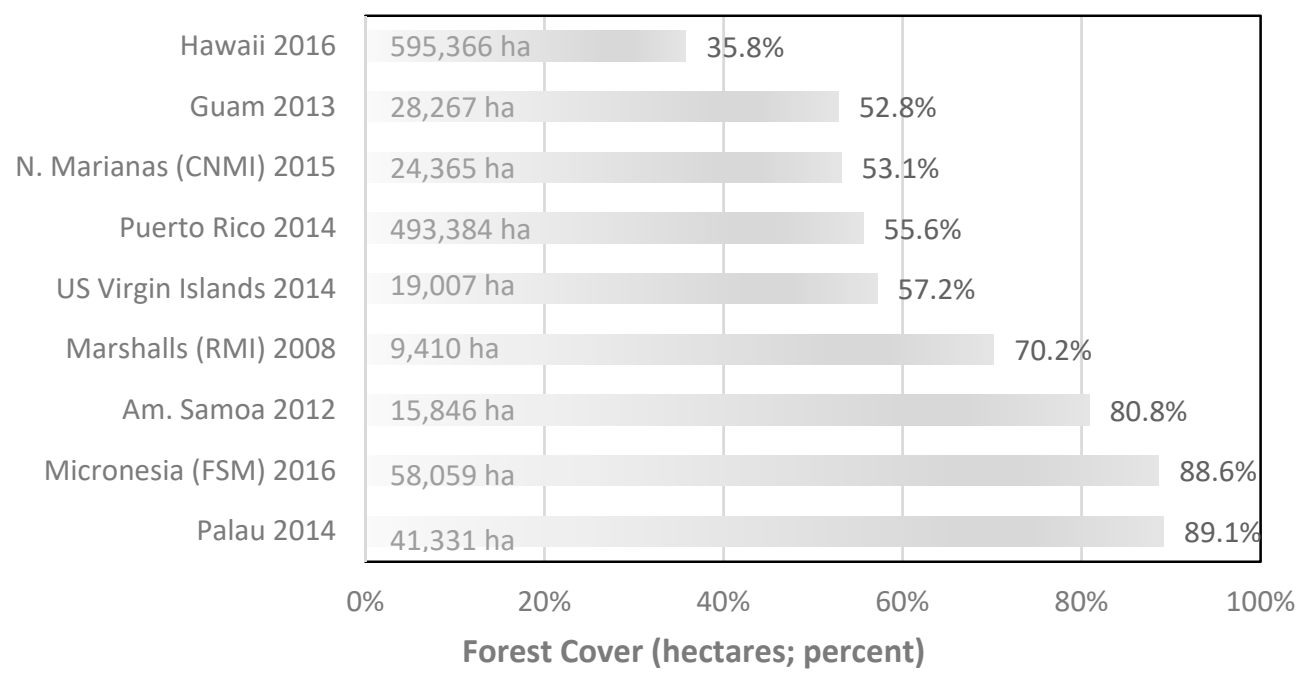

Figure 2. Forest cover in hectares and as a percentage of total land area for U.S. and U.S.-affiliated tropical islands (CNMI: Commonwealth of Northern Mariana Islands, RMI: Republic of Marshall Islands, FSM: Federated States of Micronesia) Source: [30].

Many of the historically deforested island jurisdictions in the Caribbean and Pacific regions have since recovered a significant portion of once cleared forest areas through regeneration, planting, or both, mostly on agricultural lands that were abandoned with changes in socioeconomic dynamics tied to industrialization, urbanization, globalization, and other processes $[37,38]$. Some forest recovery also has occurred as a result of environmental legislation and conservation efforts [39]. Presently, a large portion of the total forest area across the islands is classified in early to middle stages of succession, dominated by smaller to medium diameter trees $(<28 \mathrm{~cm}$ diameter at breast height $(\mathrm{dbh}))$, indicative of younger-aged forests but also specific forest types, for example those found in drier conditions (Figure 3). Forested area in three Pacific jurisdictions is dominated by trees $>28 \mathrm{~cm} \mathrm{dbh}$ ) attributed in part to the presence of coconut trees in forest plantations and agroforests [42]. 


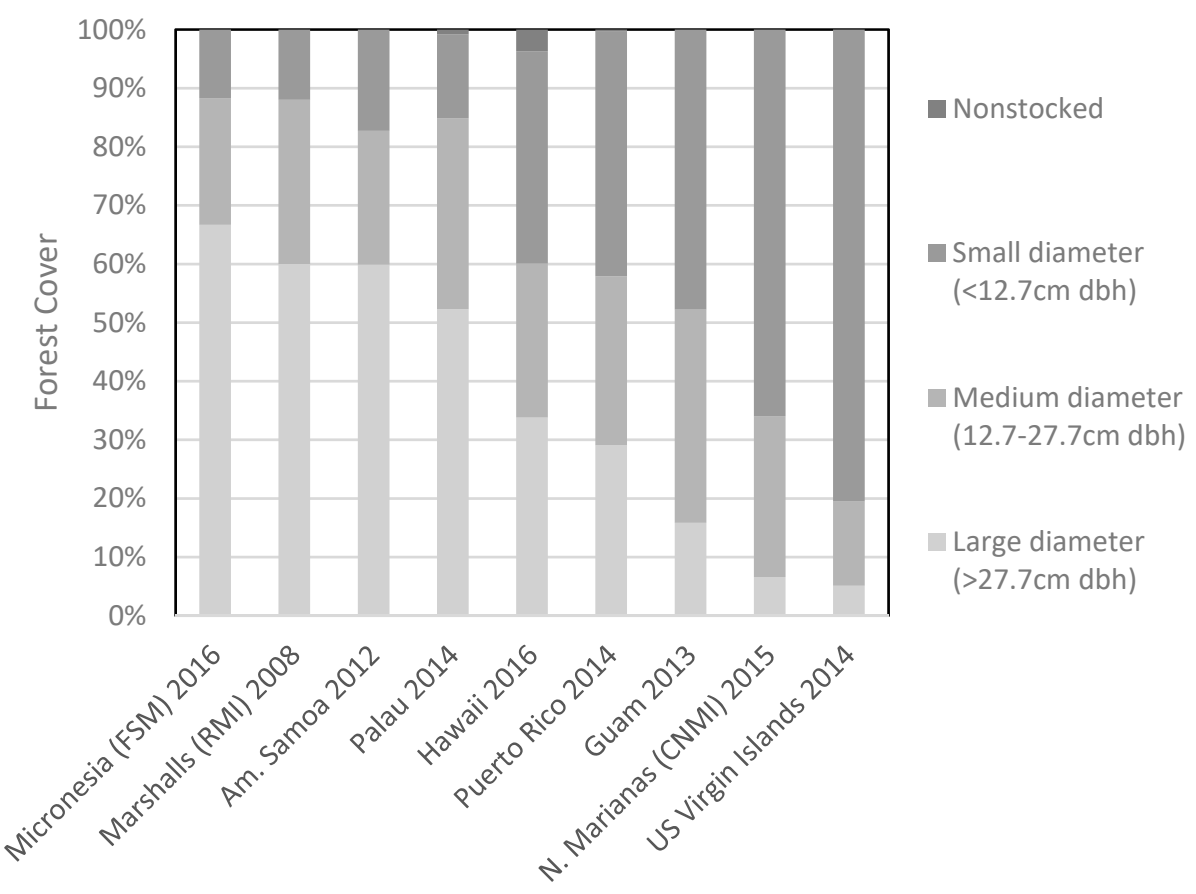

Figure 3. Forest area dominated ( $>50$ percent) by large-, medium-, small-diameter, and nonstocked stand classes (FSM: Federated States of Micronesia, CNMI: Commonwealth of Northern Mariana Islands, RMI: Republic of Marshall Islands). Source: [30].

When considered together and at the regional level, forest area across the nine jurisdictions has been relatively stable since the early 2000s, with ongoing but slowing forest recovery and expansion outpacing, for the time being, forest conversion to development, and other sources of forest loss $[30,43,44]$. For instance, when examining change in forest area in jurisdictions that had been inventoried at least twice by the U.S. Department of Agriculture (USDA) Forest Service (FS) Forest Inventory and Analysis (FIA) program at the time of this study (i.e., all jurisdictions except Hawaii and the Republic of the Marshall Islands), forests covered 645,933 ha (inventory years 2001-2005) [30]. By the early 2010s (inventory years 2012-2016), forests on these islands covered 674,966 ha demonstrating a slight increase (4.3 percent, $p<0.05)$ [30]. Nevertheless, examining forest area trends across the islands as a whole and at regional levels masks some of the finer scale dynamics including, for example, subjurisdictional losses, mostly to development, in American Samoa, and increases through forest recovery and regeneration, for example in Guam and Palau [30,45,46].

Most forested land across the islands is privately or communally owned, except in Palau (30 percent), Hawaii (47 percent), and Guam (50 percent), where more than half of forest area falls under public (i.e., governmental) ownership [30]. There also is a wide range amongst the islands in terms of the area and percentage of forests that are formally or legally protected through parks, reserves, protected areas, and other official measures [25]. Comparable information on strictly protected forest area (i.e., areas permanently protection and primarily managed for biodiversity) was available only for Hawaii (13.1 percent), Puerto Rico (11.6 percent), and the U.S. Virgin Islands (14.7 percent). When considering forests that are officially protected or actively managed and where land use change is prohibited, Hawaii has the most protected or managed forest area at 43 percent [47]. American Samoa, Guam, and Palau have at least 20 percent of their forested land protected in these categories [48] and the remaining five jurisdictions between 10 and 20 percent [48-50]. Many of the islands also have other long established or more recently developed forms of forest protection through traditional practices, collaborative arrangements, and private measures, but these are not directly measured or tracked over time. 
Owing in part to their relatively small land bases and isolation from continental land masses, the forests across these Caribbean and Pacific islands do not host the high levels of species richness found in mainland tropical areas, but they are relatively rich in plant and animal species on a per unit of area basis, particularly if compared to temperate systems. Hawaii has at least 10,843 documented terrestrial plant and animal species, Puerto Rico has 8980, and the U.S. Virgin Islands 2976 (includes terrestrial mammals, birds, freshwater fish, amphibians, reptiles, insects, and vascular plants) [51-59]. Puerto Rico demonstrates the highest species richness rate on a per unit area basis of the three, but caution is warranted in comparisons of species richness rates given variation in the level of documentation efforts per taxonomic group and island jurisdiction. Some scientists have described Hawaii's tropical forests as a "low-diversity extreme" within the global range of tropical forest diversity, attributed in part to their relatively young geological age (i.e., $<1$ million years) and to their remoteness, which results in longer distances and shorter time frames for plant colonization and subsequent speciation in the Hawaiian islands than older islands (e.g., Puerto Rico) or continental counterparts (e.g., Costa Rica) $[60,61]$. Consistent data and documentation on the number and richness of forest species for the remaining six island jurisdictions were not available.

Across all jurisdictions, forest biota is comprised of native and non-native species, some of which were introduced 1000 years ago and even earlier as food, timber, medicine, or ornamental resources, and many of which have become naturalized [62,63]. For example, fruit trees like mangoes (Mangifera indica) and coconuts (Cocos nucifera) are common among the trees inventoried by the FIA program in the Caribbean and Pacific [30]. Actually, species richness has increased across most if not all islands, due to species introductions and eventual naturalizations that far outnumber native species extinctions $[64,65]$.

The islands also host high numbers and rates of range-restricted species (e.g., endemic species) compared to most mainland tropical areas, due in part to the islands' relative isolation, climate, and heterogeneity of habitats $[9,27]$. Hawaii demonstrates the highest levels of documented endemism among the nine jurisdictions, with more than 99 percent of its native terrestrial insects, spiders and land snails, 90 percent of its plants, and more than 80 percent of its breeding birds classified as endemic $[55,66]$. Owing in part to their relative proximity to other islands in the Caribbean and to the American mainland, Puerto Rico and the U.S. Virgin Islands have comparatively lower rates of species endemism than Hawaii. For example, just eight percent of Puerto Rico's plants and about 20 percent of its resident breeding birds are endemic, but endemism is high among its herpetofauna (amphibians and reptiles) at 91 percent $[52,53,65,67]$.

Six hundred and forty two terrestrial plant and animal species native to the nine island jurisdictions studied have been identified as critically endangered (301), endangered (195), or vulnerable (146) to extinction by the International Union for the Conservation of Nature (IUCN) (The IUCN Red List (http://www.iucnredlist.org) is based on standard criteria with quantitative thresholds for population and range size, structure, and trends used to assign species to categories of extinction risk from 'least concern' to 'critically endangered', as well as 'extinct in the wild' and 'extinct'). (Table 3). The U.S. Fish and Wildlife Service (FWS) also lists species at-risk of extinction under the provisions of the Endangered Species Act and identifies 473 plant and animal species as endangered or threatened with extinction in the U.S. Virgin Islands, Puerto Rico, Hawaii, American Samoa, Marshall Islands, and Guam (the FWS does not develop species listings for the freely associated states). (There is approximately 70 percent concurrence between the species listed by the IUCN and FWS for the six jurisdictions addressed by both institutions. The IUCN lists proportionately more animals (54 percent), whereas the FWS lists proportionately more plants (71 percent). Differences in the lists likely are due to differing approaches to and criteria for species listings). Both lists include a large number of endemic species, whose extirpation could result in the extinction of the global population and a permanent loss to species richness worldwide. On a per unit of area basis, the rates of endangerment across these islands are similar to other biodiversity hotspots but generally higher than those found in the mainland tropics and orders of magnitude higher than those encountered in the continental United 
States [68-70]. A wide array of on- and off- site efforts to protect at-risk forest species and their diversity occur throughout the islands, including jurisdictional, federal, and civil society efforts to protect and recover species and their habitat.

Table 3. At-risk forest associated plant and animal species listed by the International Union for the Conservation of Nature (IUCN) and by the U.S. Fish and Wildlife Service (FWS) in tropical islands of and politically affiliated with the U.S. (listed east to west).

\begin{tabular}{cccccc}
\hline & \multicolumn{2}{c}{ IUCN } & \multicolumn{2}{c}{ FWS } \\
\hline & Critically Endangered & Endangered & Vulnerable & Endangered & Threatened \\
\hline US Virgin Islands & 10 & 11 & 5 & 8 & 2 \\
Puerto Rico & 35 & 33 & 28 & 57 & 12 \\
Hawaii & 204 & 87 & 62 & 339 & 8 \\
Am. Samoa & 2 & 9 & 10 & 24 & 3 \\
Marshalls (RMI) & 0 & 3 & 4 & 9 & 1 \\
Micronesia (FSM) & 6 & 12 & 11 & & \\
N. Marianas (CNMI) & 9 & 11 & 9 & 9 & 1 \\
Guam & 8 & 13 & 9 & & \\
Palau & 27 & 16 & 8 & & \\
\hline
\end{tabular}

Source: [71,72]; see websites for detailed category definitions.

The IUCN lists approximately 120 known extinctions of documented terrestrial species associated with these nine island jurisdictions since circa 1500 AD, almost 90 percent of which originally were found in Hawaii. Nearly 10 percent of recorded Hawaiian plants are presumed to be extinct [52]. Additionally, sixteen named forest bird species have gone extinct from Hawaii in historical times and another nine forest bird species are presumed or likely extinct $[52,56,73,74]$. These avian extinctions are attributed to a complex array of factors, including historical hunting by native islanders and European colonizers, predation by non-native species, introduced diseases, and habitat loss and fragmentation, and exacerbated by limited genetic diversity and population size and range, and many of these factors persist as pressures today [74]. Other known extinctions in the Pacific include nine of Guam's 11 documented ground-dwelling birds, whose extirpation is largely attributed to predation by the non-native brown tree snake (Boiga irregularis) [75].

Documented extinctions in the Caribbean are somewhat lower than those reported for Hawaii, despite clearance and conversion of at least 95 percent of native forest to other land uses by the 1940s [76,77]. Use of shade trees in the coffee region and the growth of secondary forest patches across the island meant that forest cover never really fell below 10 to 15 percent, which aided in the protection of native fauna and flora [76]. Brash [78] documented the extirpation of seven known native Puerto Rican bird species since human settlement (12 percent of originally documented bird fauna), including four endemic birds, but also documented the overall increase in breeding bird species on the island by the mid-1980s (97 species) - 37 more than in pre-Colombian times.

\subsection{Maintenance of the Productive Capacity of Forest Ecosystems: MP Criterion 2}

Criterion 2 focuses on forest productivity and the sustainability of timber and non-timber forest product (NTFPs) removals. Given ongoing forest inventory activity conducted by the USDA Forest Service FIA program across all island jurisdictions, there were fairly extensive data on some aspects important for this criterion including forest stocking and planted forest area and composition. Data on wood and nonwood harvest levels were more limited, coming from single point-in-time studies or anecdotal evidence, and not directly comparable across jurisdictions.

Very little of the forested area in any jurisdiction is actively managed or harvested for timber or other wood products, with the exception of parts of Hawaii where there is a small, established, and active timber industry and a discernible area of forest plantations (about 28,500 ha; 4.7 percent of total forest area) [79]. Most of the forested land on these islands is dominated by small $(<13 \mathrm{~cm} \mathrm{dbh})$ 
and medium ( $<28 \mathrm{~cm}$ dbh) diameter trees (except the Marshall Islands where non-timber coconut trees account for higher average diameters) (Figure 3), indicative of younger aged stands in the process of recovery, but also reflecting typical structural characteristics associated with drier climatic conditions on some islands, as well as the effects of frequent storms and other nonhuman and human disturbance processes common throughout the islands [32-34,43-46,80-83]. Very limited amounts of wood found in these forests are suitable for solid wood products at present, but more may be so in the future depending on stocking, growth rates, and applied management practices.

Forest plantations cover a total of at least 32,000 ha in the U.S. Virgin Islands, Puerto Rico, Hawaii, Guam, and Palau, 86 percent of which are located in Hawaii (no data were available for the other jurisdictions). These plantations are primarily stocked with non-native timber species, including Eucalyptus spp., Swietenia spp., and Tectona spp.; some were planted for the primary purpose of timber production and others for watershed protection or restoration [79,84-87]. Hawaii is the only jurisdiction with any measurable, albeit limited, commercial timber extraction from planted and natural forests, and the only jurisdiction that actively manages planted forests for timber production. Nevertheless, inventory data from planted forests available for wood production in Hawaii indicate that the majority are over-mature or undermanaged, such that their overall productivity is diminished, at least from the perspective of maximizing timber production [88,89].

Forests are important sources of artisanal and craft wood products in all jurisdictions and are important sources of wood for building and canoe materials in the Pacific. Fuelwood is collected from forests throughout both regions and is particularly important in the Pacific islands. There is some indication that the harvest of a few specific nontimber forest resources in certain settings is approaching or exceeding available stocks, particularly in the case of Santalum spp. and Acacia koa in Hawaii [89] and fuelwood collected from mangrove forests in the Federated States of Micronesia [90]. Nevertheless, nontimber wood product harvests are not actively monitored in any jurisdiction. Island forests also are important sources of nonwood forest products, such as nutritional, artisanal, recreational, cultural, and spiritual resources, which are particularly important in the Pacific islands where forests frequently are relied upon for subsistence [5]. However, information on nonwood forest product growth and extraction is not systematically collected or analyzed in any jurisdiction.

\subsection{Maintenance of Ecosystem Health and Vitality: MP Criterion 3}

Criterion 3 focuses on forest areas affected by abiotic (e.g., land clearance, fire, storm, climate change) and biotic (e.g., insects, disease, non-native invasive species) factors beyond "reference conditions" (a term that remains open to interpretation). Some data on specific insects, disease, and other biotic factors that affect forests, as well as abiotic factors, including storms and forest conversion to other land uses, were available across all jurisdictions to varying degrees. Yet, comparatively very little data were available on the area or percent of forest affected by any of these factors beyond the reference point of pre-settlement conditions.

Forest land clearance was a widespread and significant disturbance during colonization of many of the islands, as discussed above, and continues to occur, albeit on a greatly reduced scale, mostly for development [32-34,38,43-46]. Fire occurs naturally on islands with active volcanoes, but fire from lightning strikes is rare [91,92]. Apart from lava ignitions, most fire affecting the islands' forests is anthropogenic and has increased since human settlement and subsequent population expansion, particularly in the western Pacific, where it occurs in non-native and novel grasslands and along forest edges, and in dry areas of Hawaii and of southern and western Puerto Rico [91,92]. Storms, including hurricanes (in the Caribbean) and typhoons (west of the international dateline) are a regular phenomenon in the tropics and range in their strength and frequency and in their effects on the islands' forests from one point or period of time to another. Yet, as extreme weather events are predicted to occur more frequently and increase in intensity with the changing climate [2,3], the capacity of some forest species and ecosystems to recover from storms may be moderated by the effects from local land use histories and the influence from other disturbances (e.g., fire, non-native species introductions) [93]. 
In addition, although many of the effects of climate change may still be largely within the range of natural variation, increased flooding intensity and events and salt water intrusion associated in part with climate-induced sea-level rise already are in evidence in some jurisdictions, particularly in lower lying and atoll islands (Table 4) [94-96].

Table 4. Relative sea level trends and equivalent 100 year change reported by the U.S. National Oceanic and Atmospheric Administration based on monthly mean sea level data over the entirety of the available data range measured by tide gauges at long term monitoring sites in the Caribbean and Pacific (listed east to west) [97].

\begin{tabular}{ccccc}
\hline Station Location & $\begin{array}{c}\text { Data } \\
\text { Range }\end{array}$ & $\begin{array}{c}\text { Relative Sea Level } \\
\text { Trend }(\mathbf{m m})\end{array}$ & $\begin{array}{c}\mathbf{9 5 \%} \text { Confidence } \\
\text { Interval }\end{array}$ & $\begin{array}{c}\text { Equivalent 100 } \\
\text { Year Change }(\mathbf{m})\end{array}$ \\
\hline $\begin{array}{c}\text { Lime Tree Bay, } \\
\text { U.S. Virgin Islands }\end{array}$ & $1977-2018$ & 2.50 & $+/-0.71$ & 0.250 \\
Charlotte Amalie, & $1975-2018$ & 2.06 & $+/-0.63$ & 0.207 \\
U.S. Virgin Islands & $1962-2018$ & 2.04 & $+/-0.39$ & 0.204 \\
San Juan, Puerto Rico & 1.82 & $+/-0.31$ & 0.183 \\
Magueyes Island, & $1955-2018$ & 1.67 & $+/-0.43$ & 0.167 \\
$\quad$ Puerto Rico & $1995-2018$ & 1.49 & $+/-0.21$ & 0.149 \\
Nawiliwili, Hawaii & $1905-2018$ & 1.45 & $+/-0.53$ & 0.149 \\
Honolulu, Hawaii & $1957-2018$ & 2.18 & $+/-0.41$ & 0.219 \\
Mokuoloe, Hawaii & $1947-2018$ & 3.08 & $+/-0.30$ & 0.308 \\
Kahului, Hawaii & $1927-2018$ & 2.11 & $+/-0.81$ & 0.223 \\
Hilo, Hawaii & & & 0.189 \\
Pago Pago, & $1948-2009$ & 1.88 & $+/-0.68$ & \\
American Samoa & & & &
\end{tabular}

The islands also differ in the degree to which their native ecosystems have been affected by biotic agents and processes, such as insects, disease, and non-native species deemed invasive (i.e., found to be spreading, regarded as a threat to a native species or ecosystem, and/or causing negative socio-economic impacts). Data from the FIA on forest health do not indicate any widespread tree effects from insects or diseases on trees, with the exception of the Republic of the Marshall Islands, where 18.5 percent of trees were affected by insects, all by foliar injury to one tree species, Scaevola taccada [82]. Hawaii also may be an exception, with some evidence indicating that Koa wilt (Fusarium oxysporum, affecting Acacia koa) is present on all Hawaiian islands at elevations up to about $2100 \mathrm{~m}$ with high incidence and mortality rates found in Koa plantations below about $900 \mathrm{~m}$ in elevation [98,99].

Non-native plant and animal species have been introduced in large numbers to the islands, intentionally or unintentionally, by early island settlers to current residents and modern commercial activity. Of these introductions, some are valuable or harmless, some have become naturalized, and some have spread to the point of negatively affecting native species or ecosystems and/or having negative socioeconomic effects. The numbers of invasive terrestrial species listed in the Global Invasive Species Database (GISD) administered by the IUCN range from 48 in the U.S. Virgin Islands to 247 in Hawaii (Table 5). 
Table 5. Number of documented invasive terrestrial species in the U.S. and U.S. affiliated tropical islands (listed east to west).

\begin{tabular}{cccccccccc}
\hline \multirow{2}{*}{ Taxonomic Group } & \multicolumn{7}{c}{ Number of Documented Invasive Species } \\
\cline { 2 - 10 } & USVI & PR & HI & AS & CNMI & FSM & RMI & GM & PU \\
\hline Mammals & 7 & 7 & 15 & 5 & 6 & 7 & 10 & 8 & 6 \\
Birds & 1 & 6 & 10 & 2 & 3 & 1 & 1 & 4 & 1 \\
Amphibians & 3 & 3 & 5 & 1 & 1 & 1 & 1 & 3 & 1 \\
Reptiles & 0 & 4 & 8 & 2 & 2 & 4 & 5 & 5 & 2 \\
Insects & 12 & 14 & 28 & 8 & 6 & 6 & 9 & 12 & 8 \\
Snails & 0 & 0 & 5 & 2 & 1 & 1 & 2 & 3 & 2 \\
Plants & 25 & 57 & 176 & 41 & 45 & 62 & 52 & 67 & 52 \\
Total & 48 & 91 & 247 & 61 & 64 & 82 & 80 & 102 & 72 \\
\hline
\end{tabular}

Source: [100]; USVI: U.S. Virgin Islands, PR: Puerto Rico, HI: Hawaii, AS: American Samoa, CNMI: Commonwealth of Northern Mariana Islands, FSM: Federated States of Micronesia, RMI: Republic of Marshall Islands, GM: Guam, PU: Palau].

In the extreme case among the islands, Hawaii has seen some 10,000 plant species introductions since initial settlement [52], of these about 1150 grow naturally outside of cultivation, and 176 are listed as invasive in the GISD, by far the most listed for any jurisdiction. Hawaii also accounts for the highest number of invasive animals listed by the IUCN. Animals deemed invasive affecting island forests include feral and unmanaged ungulates (e.g., pigs, goats) that overbrowse or trample established and emerging forest vegetation, and non-native predators (e.g., snakes, rats, cats) that prey on native birds and other animals, including their eggs, which can cause attendant secondary effects on pollination and dispersal [101,102].

A key consideration for many of these islands centers on the effects of non-native species introductions on native biodiversity. For instance, do non-native species replace native species, leading to localized or permanent extirpation?; do they co-occur with native species without significant negative effects in native populations?; do they provide a favorable environment for native species regeneration? The answers to these questions are specific to particular species, locations, and points in time. In Puerto Rico, where forest recovery may be further advanced than most jurisdictions in the study, mono-specific stands of non-native plants that once dominated abandoned agricultural sites have since given way to novel forest communities comprised of new combinations of native and non-native species that function and provide multiple ecosystem services at levels similar to or higher than native forests $[103,104]$. For example, the introduced African tuliptree (Spathodea campanulata) currently accounts for the greatest number of trees and most live tree basal area of all tree species inventoried by the USDA Forest Service FIA program, yet the next three most important tree species are native to Puerto Rico, demonstrating the capacity of native species to regenerate and compete with non-native species and their ability to recolonize secondary forest associations in landscapes significantly altered by human activities [43]. Introduced plant species in Puerto Rico include 16 documented invasive tree species listed by the Global Invasive Species Database out of a total of 123 introduced tree species documented by Francis et al. [105]. Many of these non-native species have extended their range in the wild, yet none have been documented to permanently replace native tree species in Puerto Rico.

A quite different process has been documented in Hawaii, where some native forest species have not been as successful in competing with or fending off non-native species, attributed in part to their evolution across niches and in near isolation, such that fewer species are able to outcompete the broad range of growth strategies demonstrated by some non-native plant species or are not equipped with self-defense mechanisms to fend off predation or herbivory by some non-native animal species [106]. Documented shifts in Hawaii's forest composition have resulted from the spread of non-native species that eventually dominate areas previously classified as native forest, including stands of native Ohia (Metrosideros polymorpha) that have become dominated by Albizia (Falcataria moluccana), a non-native 
tree species, and expanding areas of Ohia forest that have been affected by Rapid Ohia Death, caused by the spread of and damage from non-native pathogens (i.e., Ceratocystis lukuohia, C. huliohia) [107-112]. Additionally, non-native grasslands dominated by Pennisetum clandestinum have replaced areas once dominated by native forests, particularly in Hawaii's drier life zones and where compacted soils and fire impede competition from native plant species, impeding native or novel forest recovery for now at least, or not without intensive human intervention [107-112].

\subsection{Conservation and Maintenance of Soil and Water Resources: MP Criterion 4}

Criterion 4 focuses on the status and conservation of forest soil and water resources, including the area and percent of forests designated specifically for soil and water protection. Qualitative data on forest conservation efforts were available for all jurisdictions, but quantitative, comparable data on forest water and soil conditions were quite limited.

Much of the islands' secondary forest area occurs on compacted, eroded, or otherwise degraded soils and with diminished water resources owing to the land use histories that predate them. In some areas, the establishment and maturation of these secondary forests actually contributes to the recuperation, maintenance, or protection of soil and water resources (see for example [38]). On many of the inhabited islands and particularly notable in Hawaii and part of the Pacific are the effects of feral ungulate (e.g., pigs, goats) activity that results in uprooting of vegetation, exposure of soil and subsoil, and dispersal of non-native grasses and other plant species in forests from early to late successional stages [113,114]. Water withdrawals and diversions from forested areas also occur to varying degrees where available, but water extraction levels and the associated effects on forests have been little studied (for exceptions see $[115,116]$ ).

Forests across the islands are protected for a range of values, including the conservation of soil and water resources to varying degrees (see Section 4.1). Forests also have been (re)planted on most islands for the primary purpose of watershed restoration or protection. In the Caribbean, the protection of riparian zones is mandated by law but rarely monitored or enforced [117,118]. Additional measures have been taken to protect and conserve the soil and water resources in critical watersheds through active partnerships between government, civil society, and the private sector in a few jurisdictions, including efforts led by the Hawaii Watershed Protection Board and watershed protection efforts initiated through the Micronesia Challenge. Voluntary best management practices (BMPs) for forest use and conservation that include the protection of soil and water resources are available in Hawaii and Puerto Rico. Additionally, the USDA Forest Service Forest Stewardship Program, which is active in most jurisdictions, promotes long-term forest management that takes into account soil, water, wildlife, and other forest values through technical and financial assistance for forest planning and operations.

\subsection{Maintenance of Forest Contribution to Global Carbon Cycles: MP Criterion 5}

Criterion 5 focuses on carbon stocks and fluxes in forests. Forest carbon estimates for Puerto Rico and the U.S. Virgin Islands were available from the FIA and forthcoming for the other jurisdictions based on the most recent measurements but not available at the time of this study. Very little to no data on forest product carbon stocks and fluxes or avoided fossil fuel carbon emissions from the use of wood as energy were available for the islands.

Carbon stock estimates range widely across the islands owing to their size, and forest area, types, and conditions. For instance, aboveground carbon (C) stocks in live trees greater than $2.54 \mathrm{~cm}$ were estimated at 20.4 million metric tons and 41.47 metric tons/ha in Puerto Rico and 0.55 million metric tons and 30.3 metric tons/ha in the US Virgin Islands [33,34]. Carbon stocks in the islands' forests generally fluctuate in response to storms, hurricanes or typhoons, and other disturbances that can lead to short term losses followed by increases as forests recover [119]. Furthermore, while total island forest carbon stocks generally are small compared to continental levels, some stocks such as those in forest wetland soils across the islands, including mangroves, are relatively large per unit of area [120]. 
In Hawaii, total carbon stored in terrestrial ecosystems across the main islands (i.e., Hawaii, Maui, Molokai, Lanai, Kahoolawe, Oahu, Kauai) was estimated at 258 million metric tons of carbon in 2014 and showed an average annual increase of 20.2 metric tons of carbon between 2003 and 2014 [121]. Puerto Rico also has been a carbon sink for decades with net positive fluxes as forests have recovered and expanded, but these fluxes have tapered off and may be approaching net zero change as forest expansion levels off [33,43]. In the U.S. Virgin Islands, net losses of forest carbon resulting from the loss of forested area were reported during 1994-2004, but these negative carbon fluxes largely have tapered off since as forest loss slowed and approached stability $[34,44]$. Data on carbon fluxes were not available for other jurisdictions.

\subsection{Maintenance and Enhancement of Long-Term Socioeconomic Benefits: MP Criterion 6}

Criterion 6 focuses on the socioeconomic dimensions of forest sustainability. Data focused on forest benefits, activities, and other forest-related socioeconomic dimensions for addressing this criterion were very limited and, when available, mostly disparate and difficult to compare across the islands. Well-defined forest economic sectors are generally associated with multiple statistical measures that can be used to examine this criterion, but such sectors are largely absent in the islands. Given these data limitations, we examined this criterion at the sub-criterion level (rather than examining the 20 associated indicators individually), considering (1) production, consumption, and trade in forest products; (2) investment in the forest sector; (3) forest employment and community needs; (4) recreation and tourism; and (5) cultural, social and spiritual aspects, though even at this more general level data restrictions applied.

Production of wood and nonwood products from forests occurs in all jurisdictions (e.g., lumber, craftwood products, musical instruments, fuel, fiber, fruits, game meat, medicinals, resins, oils, etc.), though the magnitude of these production activities is largely unspecified in the data $[85,86,89,90,122-126]$. Some of these products are sold in local or even export markets, albeit in very limited cases, some are bartered, and many are used for subsistence. Forest food production through gathering, hunting, and agroforestry is important for many island inhabitants and for local livelihoods and economies, and is reflected in part in the pervasiveness of fruit and other food trees throughout much of the islands' forests. In the Republic of the Marshall Islands, studies have shown that copra production, handicrafts, and "subsistence" use of forests comprise 54 percent of overall household production $[5,30,127,128]$. Other studies have demonstrated the importance and economic value of forest products, including mangrove crabs, wild pig meat, and wood to subsistence economies in Micronesia (see for example [129,130]).

Forested areas across the islands also serve as sources of recreation, aesthetic beauty, spiritual sustenance, and often are tied to a profound sense of place for many island inhabitants, but these elements are difficult to quantify and have been little studied in the islands. Tourism, in particular, is an important sector in all jurisdictions and occurs at industrial scale in Hawaii, Guam, the Northern Marianas, Puerto Rico, and the Virgin Islands. Forests often are among the primary tourism attractions, but their contributions to the economic benefits associated with tourism are not clearly delineated or directly measured in any jurisdiction. Moreover, although forests are important to tourism and tourism may in turn contribute to a greater overall economic valuation of forests, the need to manage tourism activity associated with forests is broadly acknowledged, both from an ecological and social standpoint, particularly where recreation is unmanaged or exceeds a forest's carrying capacity and where tourism development incurs forest land use change [85,86,89,90,122-126].

\subsection{Legal, Institutional, and Economic Framework for Forests: MP Criterion 7}

Criterion 7 focuses on the legal, institutional, and economic framework that governs and promotes forest sustainability, addressing topics ranging from forest policy and laws, to public participation in forest decisions and management, to research and monitoring activities. Due to limitations in data for the $10 \mathrm{MP}$ indicators, we consolidated our reporting to focus on local government institutions, 
including land tenure and property rights, academic institutions, civil society organizations, cooperative activities, and regional collaborations supporting forests. These elements directly and indirectly address the overall focus of the criterion and information on them was available to some degree across all jurisdictions.

The heterogeneity that characterizes the ecological and social conditions in the islands is equally evident in their institutional, legal, and economic arrangements, attributable in part to their geography and to the histories and traditions unique to each of the islands. The size and nature of local government organizations determine in large part their ability to actively engage in forest management activities and to avail themselves of the various federal and international programs available to support these efforts. Five of the nine island entities have government units explicitly focused on forestry (i.e., U.S. Virgin Islands Department of Agriculture, Forestry Division; Puerto Rico Department of Natural and Environmental Resources, Forest Service Bureau; Hawaii Dept. of lands and Natural Resources, Divisions of Forestry and Wildlife; Guam Dept. of Agriculture, Division of Forestry; Republic of Palau Ministry of Natural Resources, Bureau of Agriculture, Forestry Section). The absence of explicitly identified, locally funded forestry agencies in the other four jurisdictions mostly reflects limited resources associated with smaller populations and governments but masks any integration of tropical forestry with other land management policies and programs such as those focused on coastal management or agriculture, programs that are common across all jurisdictions.

Jurisdiction-level laws, policies, and other institutions also are influenced by the association each has with the United States government, ranging from statehood (Hawaii) to commonwealth or territorial status (Commonwealth of the Northern Mariana Islands, American Samoa, Guam, Puerto Rico, and the U.S. Virgin Islands) to independent countries in compacts of free association with the United States (Federated States of Micronesia, Republic of the Marshall Islands, and Republic of Palau) (Table 2). These different types of association each carry different rights, constraints, and institutional arrangements in regards to the U.S. Government in general and federal land management and environmental laws and agencies in particular. Applicable U.S. national laws and regulations protect public benefits arising from forests and prevent negative effects to natural resources such as wetlands, water and air quality, wildlife, and threatened and endangered species to varying degrees in all jurisdictions. For instance, the Endangered Species Act of 1973 (ESA; 7 U.S.C. § 136, 16 U.S.C. § 1531 et seq.) is applied in all the islands, including the freely associated states of Micronesia, Palau, and the Marshall Islands as a legacy of these islands' status until 1986 as Trust Territories administered by the United States.

All jurisdictions have systems in place that identify property and outline the rights associated with that property and its transfer, including due process relative to the loss of property or property rights. Four Pacific jurisdictions forbid outright land ownership by individuals that are not native or of island descent (i.e., Federated States of Micronesia, Commonwealth of the Northern Mariana Islands, Republic of the Marshall Islands). In these islands, dual tenure systems are common, with lands governed by private or public property rights that also fall under communal property regimes or tenure arrangements, which may be governed by a chief or Matai. In the Caribbean and the state of Hawaii, cultural and historical traditions are recognized through historical preservation laws, but no property rights or land tenure privileges are accorded through traditional practices or to any one group to the exclusion of others.

Academic institutions on the islands range considerably in their size and the degrees they confer; all jurisdictions have degree programs in agriculture, most in natural resources or environmental sciences, but none with an undergraduate or graduate degree in forestry or forest resource management and conservation. All but Palau and the Republic of the Marshall Islands host land-grant universities or colleges and receive Hatch and Smith-Lever funding for agricultural research and extension, including forestry and agroforestry programs. Civil society organizations also play a prominent role in promoting resource conservation and local development needs throughout the islands. They facilitate community participation and often act as a link between local, national, and international 
actors and their related resources. Additionally, regional collaboration provides an opportunity for islands to pool their resources, learn from each other, and leverage outside resources from academia, the federal government, or NGOs. The most significant development comes from the Pacific through the "Micronesia Challenge", founded by the heads of state of the Republic of the Marshall Islands, Federated States of Micronesia, Commonwealth of Northern Mariana Islands, Guam, and Palau in 2006 to "effectively conserve" at least 20 percent of the terrestrial resources (land acreage) in each jurisdiction by 2020, with all well on their way to meeting this goal, including American Samoa, Guam, and Palau which already have met or surpassed it [48].

\section{Discussion}

\subsection{Island Forest Conditions and Trends Important to Assessing Sustainability}

When we considered available data on ecological, economic, and social forest conditions and trends across the nine island jurisdictions through the lens of the MP C\&I framework, several trends stood out as having direct bearing on the overall question of forest sustainability. First, forest area across the islands has been relatively stable at regional and study-wide scales over the past decade or so (i.e., 2000s-2010s), with forest losses, attributed primarily to development pressures, largely being offset by forest gains mostly from ongoing forest recovery on abandoned agriculture and grazing lands [32-34,43-46]. This trend is a positive signal for sustainability, particularly when forest losses are prominent elsewhere throughout the tropics [1]. Still, net forest losses at jurisdictional and sub-jurisdictional levels do not meet this most basic element of sustainability, warranting further research and monitoring to understand the associated causes and drivers and inform sound practice and policy.

Second, some elements of the islands' native biodiversity are threatened by multiple factors, including the loss of habitat and plant and animal species deemed invasive when they displace, disturb, prey on, or otherwise affect species to the point of population declines. These effects tend to be magnified where species endemism is high. Hawaii's biota stands out amongst the islands, having been highly studied and having the highest numbers and rates of at-risk species across major taxonomic groups [52]. Many of these species are endemic and their extirpation or extinction would mean a decline in global biodiversity. Habitat loss and invasive species are the top two threats cited in the at-risk species listings across all jurisdictions and factor prominently in the designation of biodiversity hotspots that include both regions (i.e., Caribbean Hotspot, Polynesian-Micronesian Hotspots) [10-12,68].

Third, new or 'novel' assemblages of non-native and native plant species are maturing over large areas and portions of many of the islands, predominately on abandoned agricultural lands cleared of native forests long ago. These forests typically are dominated by non-native and by smaller$(<13 \mathrm{~cm} \mathrm{dbh})$ and medium-stemmed (13-28 cm dbh) trees, limiting commercial timber uses, for now at least, but contributing to the restoration and provision of ecosystem services at levels similar to or even higher than native forests $[64,103,104,106]$. The implications of this trend to sustainability depend greatly on the future trajectory of these novel ecosystems in the specific social-ecological settings in which they occur and how sustainability is defined and delineated in its component parts and processes. While we do not pretend nor attempt to solve here the ongoing debates associated with 'native' versus 'novel' (see for example [131-133]), we do contend that comprehensive assessments such as this, which provide socioeconomic as well as biophysical information, help us better understand the full dimensions of forest functionality, thus shedding light on this question, as well as more general questions about forest sustainability, desired future conditions, and appropriate management actions.

Other major findings include (1) the importance of island forests as sources of food, medicinal supplies, wood for crafts and construction, and other materials for cultural purposes and daily use. Although commercial timber production is limited to Hawaii, where it occurs only on a small scale, many islanders depend on forests for their livelihoods and subsistence, particularly in the Pacific, where 
with the exception of Hawaii, per-capita incomes are less than half the U.S. average and subsistence activities are important supplements to other sources of nutrition, household income, health, and life quality. (2) The potential effects of climate change threaten entire islands and ecosystems, given their susceptibility to sea-level rise, storm activity, and other disturbances, especially inhabited atoll islands that do not rise more than 10 masl [2,3]. (3) Limited domestic resources and insufficient economies of scale make it difficult to address these and other forest management challenges locally, though many islands actively engage in regional collaboration and exchange (e.g., in higher education) and have instituted cross-boundary partnerships incorporating nongovernmental organizations, citizens groups, local and federal governments, and private sector representatives to overcome some of these challenges and associated limitations.

\subsection{Data Availability and Adequacy Important to Assessing Sustainability}

Data availability and adequacy for assessing forest sustainability is an important meta-question that should be addressed in any comprehensive study such as this. We found that data that are both consistent over time and comparable across island jurisdictions are relatively rare. The USDA Forest Service has periodically measured forests through the FIA program in Puerto Rico since the mid-1980s and in the U.S. Virgin Islands since the mid-1990s, moving to cyclical measurements in 2014. More recently, the FIA completed a second measurement of forests in the Pacific islands, allowing for comparable status and trend data on forest area, species composition, tree age, volume stocking levels, and a variety of other biophysical measures across all jurisdictions, except Hawaii, which had only been measured once at the time of this study, though a second complete round of measurements are scheduled for 2019-2021 [30]. The establishment of consistent biophysical inventory activities constitutes a major improvement in data provision for management and assessment in the islands. U.S. Census and related socioeconomic information also are available but limited in their relation to forests and not always directly comparable across different jurisdictions, especially for the freely associated states (Republic of the Marshall Islands, Federated States of Micronesia, and Republic of Palau).

Improvements in data availability notwithstanding, much of the information required for comprehensive forest sustainability reporting in the tropical islands considered here is hard to find, reconcile, and compile, or it is simply unavailable. The lack of complete data is further compounded by island geographies, where heterogeneity makes comparison difficult and isolation makes measurement expensive. Noted data gaps include basic forestry information such as the distribution of species and forest soil and water conditions. On the social front, much of our understanding of the relationships between people and forests in the islands is based on anecdotal information and some scattered one-off studies, where it exists at all. In terms of institutions, we have yet to devise adequate measures, much less populate them with relevant data, even though we know that institutions are crucial to securing sustainable forest management.

\subsection{Utility of the MP CEI in Assessing Sustainability in Tropical Island Forests}

In general, the MP C\&I's stated focus on temperate and boreal forests did not present problems when applied to the tropical island forests included in this study. The biophysical indicators are general enough to be equally applicable in tropical settings. However, aspects of the MP C\&I that focus on timber production were largely irrelevant to these islands at this point in time, since the majority have minimal to nonexistent wood products production activity. Conversely, many of the forest outputs and activities valued by island residents are under-represented in the MP C\&I, and this is especially true in the area of agroforestry, common throughout the islands, particularly in the South Pacific. The MP C\&I does contain a limited number of indicators on non-wood forest products and subsistence, as well as on forest-based recreation and cultural and spiritual values that are comparatively more relevant to the forests of these regions today, but our reporting in these areas is further limited by a lack of available data. 


\section{Conclusions}

Forests on U.S. and politically affiliated islands of the Caribbean and Pacific are rich and dynamic social-ecological systems that, while distinct, have key characteristics and trends in common permitting cross-island analyses that underscore the utility of sustainability assessments that go beyond single jurisdictional efforts. Such efforts require some level of comparable data and in the last decade there has been notable progress in the measurement and monitoring of key biophysical aspects of forests on these tropical islands, permitting advances in the assessment of forest sustainability in the face of various stressors. In other areas, including social and economic forest dimensions, data availability remains a major challenge.

Through the flexible application of the MP C\&I, we developed a fairly comprehensive view of forest conditions and trends within and across the islands. What emerges is a set of discreet pictures describing island conditions where net loss of forests is the exception, but dynamic changes associated with human habitation, new species introductions, and impending changes in climate present considerable challenges where human linkages to forests and their outputs are extensive even while major wood products production activities are rare.

We refrain from drawing any definitive conclusion about the 'sustainability' of Caribbean and Pacific island forests, but through a comprehensive depiction of these forests as systems, we identify areas where more analysis and, ultimately, policy responses merit increased attention. In this application, "sustainability" in general and the MP C\&I in particular serve as organizing principles for the presentation of information, information that ideally will inform discussions, decisions and actions to address the many challenges facing these unique social-ecological systems and sustain them into the future.

Author Contributions: Conceptualization, K.A.M., G.C.R.; methodology, K.A.M., G.C.R., K.S.F.; formal analysis, K.A.M., G.C.R., K.S.F.; investigation, K.A.M., G.C.R., K.S.F.; writing一original draft preparation, K.A.M., G.C.R.; writing-review and editing, K.M., G.C.R.; visualization, K.A.M.

Funding: This research was funded by the USDA Forest Service.

Acknowledgments: We thank Constance Carpenter who was instrumental in initiating this project and convening the collaboration between the Caribbean and Pacific regions. We also thank Ariel E. Lugo and two anonymous reviewers whose insightful comments improved this manuscript, and Thomas J. Brandeis and Humfredo Marcano-Vega for useful input and discussions on the data. The research was done in cooperation with the University of Puerto Rico.

Conflicts of Interest: The authors declare no conflicts of interest.

\section{References}

1. Intergovernmental Science-Policy Platform on Biodiversity and Ecosystem Services. Summary for Policymakers of the Global Assessment Report on Biodiversity and Ecosystem Services of the Intergovernmental Science-Policy Platform on Biodiversity and Ecosystem Services; Díaz, J., Settele, E.S., Brondizio, E.S., Ngo, M., Guèze, J., Agard, A., Arneth, P., Balvanera, K.A., Brauman, S.H.M., Butchart, K.M.A., et al., Eds.; IPBES secretariat: Bonn, Germany, 2019.

2. Keener, V.; Helweg, D.; Asam, S.; Balwani, S.; Burkett, M.; Fletcher, C.; Giambelluca, T.; Grecni, Z.; Nobrega-Olivera, M.; Polovina, J.; et al. CHAPTER 27: HAWAI'I AND U.S.-AFFILIATED PACIFIC ISLANDS. In Impacts, Risks, and Adaptation in the United States: Fourth National Climate Assessment; Reidmiller, D.R., Avery, C.W., Easterling, D.R., Kunkel, K.E., Lewis, K.L.M., Maycock, T.K., Stewart, B.C., Eds.; U.S. Global Change Research Program: Washington, DC, USA, 2018; Volume II, pp. 1242-1308. [CrossRef]

3. Gould, W.A.; Díaz, E.L.; Álvarez-Berríos, N.L.; Aponte-González, F.; Archibald, W.; Bowden, J.H.; Carrubba, L.; Crespo, W.; Fain, S.J.; González, G.; et al. CHAPTER 20: U.S. CARIBBEAN. In Impacts, Risks, and Adaptation in the United States: Fourth National Climate Assessment; Reidmiller, D.R., Avery, C.W., Easterling, D.R., Kunkel, K.E., Lewis, K.L.M., Maycock, T.K., Stewart, B.C., Eds.; U.S. Global Change Research Program: Washington, DC, USA, 2018; Volume II, pp. 809-871. [CrossRef] 
4. Gould, W.A.; Fain, S.J.; Pares, I.K.; McGinley, K.; Perry, A.; Steele, R.F. Caribbean Regional Climate Sub Hub Assessment of Climate Change Vulnerability and Adaptation and Mitigation Strategies; USDA Forest Service, International Institute of Tropical Forestry: Rio Piedras, PR, USA, 2015; 67p. Available online: https://www.climatehubs.oce.usda.gov/sites/default/files/Caribbean\%20Region\%20Vulnerability\% 20Assessment\%20Final.pdf (accessed on 8 September 2019).

5. Food and Agriculture Organization of the United Nations. Climate Change and Food Security in Pacific Island Countries; Food and Agriculture Organization: Rome, Italy, 2008.

6. Barker, D. Caribbean agriculture in a period of global change: Vulnerabilities and opportunities. Caribb. Stud. 2012, 40, 41-61. [CrossRef]

7. Ewel, J.; Whitmore, J.L. The Ecological Life Zones of Puerto Rico and the U.S. Virgin Islands; Research Paper IITF-18; U.S. Department of Agriculture Forest Service, Institute of Tropical Forestry: Rio Piedras, PR, USA, 1973; p. 72.

8. Tosi, J.A., Jr.; Watson, V.; Bolaños, R. Life zone maps of Hawaii, Guam, American Samoa, Northern Mariana Islands, Palau, and Micronesia; Tropical Science Center: San Jose, Costa Rica; U.S. Department of Agriculture, Forest Service, Pacific Southwest Research Station, Institute of Pacific Islands Forestry: Hilo, HI, USA, 2002.

9. Kier, G.; Kreft, H.; Lee, T.M.; Jetz, W.; Ibisch, P.L.; Nowicki, C.; Mutke, J.; Barthlott, W. A global assessment of endemism and species richness across island and mainland regions. Proc. Natl. Acad. Sci. USA 2009, 106, 9322-9327. [CrossRef] [PubMed]

10. Myers, N.; Mittermeier, R.A.; Mittermeier, C.G.; da Fonseca, G.; Kent, J. Biodiversity hotspots for conservation priorities. Nature 2000, 403, 853-858. [CrossRef] [PubMed]

11. Brooks, T.M.; Mittermeier, R.A.; Mittermeier, C.G.; da Fonseca, G.A.B.; Rylands, A.B.; Konstant, W.R.; Flick, P.; Pilgrim, J.; Oldfield, S.; Magin, G.; et al. Habitat loss and extinction in the hotspots of biodiversity. Conserv. Biol. 2002, 16, 909-923. [CrossRef]

12. Hobohm, C. Characterization and ranking of biodiversity hotspots: Centres of species richness and endemism. Biodivers. Conserv. 2003, 12, 279-287. [CrossRef]

13. World Resources Institute. Ecosystems and Human Well-being: Biodiversity Synthesis; Millenium Ecosystem Assessment; World Resources Institute: Washington, DC, USA, 2005.

14. Lammerts van Bueren, E.M.; Blom, E.M. Hierarchical Framework for the Formulation of Sustainable Forest Management Standards; The Tropenbos Foundation: Wageningen, The Netherlands, 1996.

15. Prabhu, R.; Colfer, C.J.P.; Dudley, R.G. Guidelines for Developing, Testing and Selecting Criteria and Indicators for Sustainable Forest Management: A C E I Developer's Reference; Criteria and Indicators Toolbox Series No.1; CIFOR: Bogor, Indonesia, 1999.

16. Prabhu, R.; Boyle, T.J.B.; Colfer, C.J.B. Between voodoo science and adaptive management: The role and research needs for indicators of sustainable forest management. In Criteria and Indicators for Sustainable Forest Management; IUFRO Research Series 7; Raison, R.J., Brown, A.G., Flinn, D.W., Eds.; CABI Publishing: Wallingford, UK, 2001; pp. 39-66.

17. Wijewardana, A. Criteria and indicators for sustainable forest management: The road travelled and the way ahead. Ecol. Ind. 2008, 8, 115-122. [CrossRef]

18. Arts, B.; Appelstrand, M.; Kleinschmit, D.; Pulzl, H.; Visseren-Hamakers, I.; Ebáa Atyi, R.; Enters, T.; McGinley, K.; Yasmi, Y. Discourses, actors, and instruments in international forest governance. Pages 57-74. In Embracing Complexity: Meeting the Challenges of International Forest Governance. A Global Assessment Report; Prepared by the Global Forest Expert Panel on the International Forest Regime; IUFRO World Series Volume 28; Rayner, J., Buck, A., Katila, P., Eds.; IUFRO: Vienna, Austria, 2010.

19. Baycheva-Merger, T.; Wolfslehner, B. Evaluating the implementation of the Pan-European Criteria and indicators for sustainable forest management-A SWOT analysis. Ecol. Indic. 2016, 60, 1192-1199. [CrossRef]

20. Singh, R.K.; Murty, H.R.; Gupta, S.K.; Dikshit, A.K. An overview of sustainability assessment methodologies. Ecol. Indic. 2009, 9, 189-212. [CrossRef]

21. Grainger, A. Forest sustainability indicator systems as procedural policy tools in global environmental governance. J. Glob. Environ. Chang. 2012, 22, 147-160. [CrossRef]

22. Linser, S.; Wolfslehner, B.; Asmar, F.; Bridge, S.R.J.; Gritten, D.; Guadalupe, V.; Jafari, M.; Johnson, S.; Laclau, P.; Robertson, G. 25 Years of Criteria and Indicators for Sustainable Forest Management: Why Some Intergovernmental C\&I Processes Flourished While Others Faded. Forests 2018, 9, 515. 
23. Montreal Process. Criteria and Indicators for the Conservation and Sustainable Management of Temperate and Boreal Forests, 5th ed.; Montreal Process: Tokyo, Japan, 2015; 31p. Available online: http://www.montrealprocess. org/documents/publications/techreports/Montreal-ProcessSeptember2015.pdf (accessed on 22 October 2019).

24. Pokorny, B.; Adams, M. What do criteria and indicators assess? An analysis of five C\&I sets relevant for forest management in the Brazilian Amazon. Int. For. Rev. 2003, 5, $20-28$.

25. McGinley, K.A.; Robertson, G.C.; Friday, K.S.; Carpenter, C.A. Assessing Forest Sustainability in the Tropical Islands of the United States; General Technical Report GTR-IITF-48; USDA Forest Service, International Institute of Tropical Forestry: Rio Piedras, PR, USA, 2017; p. 120.

26. MacArthur, R.H.; Wilson, E.O. The Theory of Island Biogeography; Princeton University Press: Princeton, NJ, USA, 1967; 224p.

27. Whittaker, R.J.; Fernández-Palacios, J.M. Island Biogeography: Ecology, Evolution, and Conservation, 2nd ed.; Oxford University Press: Oxford, UK, 2017; 416p.

28. U.S. Census Bureau. American Factfinder. Available online: https://factfinder.census.gov/faces/nav/jsf/pages/ index.xhtml (accessed on 17 August 2019).

29. Central Intelligence Agency of the United States. The World Factbook. Available online: https://www.cia. gov/library/publications/the-world-factbook/ (accessed on 17 August 2019).

30. USDA Forest Service. Forest Inventory and Analysis Program, EVALIDator Web-Application Version 1.8.0.00; Department of Agriculture, Forest Service, Northern Research Station: St. Paul, MN, USA, 2018. Available online: http://fsxopsx1056.fdc.fs.usda.gov:9001/Evalidator/evalidator.jsp (accessed on 10 September 2019).

31. Bennett, K.A.; Liu, Z. The Overlay of Lifezone and Vegetation Data for Hawaii, Guam, CNMI, American Samoa, and FSM. Available online: https://sites.google.com/a/spf-davis.info/office/Home/our-projects/2010tropical-island-sustainable-forest-report/the-overlay-oflifezone-and-vegetation-data-for-hawaii-guamcnmiamerican-samoa-and-fsm (accessed on 1 March 2019).

32. Brandeis, T.J.; Helmer, E.H.; Oswalt, S.N. The Status of Puerto Rico's Forests, 2003; Resour. Bull. SRS-119; U.S. Department of Agriculture, Forest Service, Southern Research Station: Asheville, NC, USA, 2007; 75p.

33. Brandeis, T.J.; Turner, J.A. Puerto Rico's Forests, 2009; Resour. Bull. SRS-RB-191; U.S. Department of Agriculture, Forest Service, Southern Research Station: Asheville, NC, USA, 2013; 85p.

34. Brandeis, T.J.; Turner, J.A. U.S. Virgin Islands, 2009_Forest Inventory and Analysis Factsheet; e-Science Update SRS-SU-077; U.S. Department of Agriculture, Forest Service, Southern Research Station: Asheville, NC, USA, 2013; 5p.

35. Holdridge, L.R. Life Zone Ecology; Tropical Science Center: San Jose, Costa Rica, 1967; 149p.

36. Lugo, A.E.; Schmidt, R.; Brown, S. Tropical forests in the Caribbean. AMBIO 1981, 10, 318-324.

37. Atkinson, Q.D.; Coomber, T.; Passmore, S.; Greenhill, S.J.; Kushnick, G. Cultural and Environmental Predictors of Pre-European Deforestation on Pacific Islands. PLoS ONE 2016, 11, e0156340. [CrossRef] [PubMed]

38. Lugo, A.E.; Helmer, E.H. Emerging forests on abandoned land: Puerto Rico's new forests. For. Ecol. Manag. 2004, 190, 145-161. [CrossRef]

39. Aide, T.M.; Grau, H.R. Globalization, migration, and Latin American ecosystems. Science 2004, 305, 1915-1916. [CrossRef]

40. Meyfroidt, P.; Lambin, E.F. Global forest transition: Prospects for an end to deforestation. Annu. Rev. Environ. Resour. 2011, 36, 343-371. [CrossRef]

41. Rudel, T.K.; Perez-Lugo, M.; Zichal, H. When fields revert to forest: Development and spontaneous reforestation in post-war Puerto Rico. Prof. Geogr. 2000, 52, 386-397. [CrossRef]

42. USDA Forest Service. Pacific Northwest Station. Forest Inventory and Analysis. Pacific Islands. Available online: https://www.fs.usda.gov/pnw/projects/pnw-fia-pacific-islands-inventory (accessed on 10 September 2019).

43. Marcano-Vega, H. Forests of Puerto Rico, 2014; Resource Update FS-121; U.S. Department of Agriculture Forest Service, Southern Research Station: Asheville, NC, USA, 2017; 4p. [CrossRef]

44. Marcano-Vega, H.; Williamson, J.R. Forests of U.S. Virgin Islands, 2014; Resource Update FS-144; U.S. Department of Agriculture Forest Service, Southern Research Station: Asheville, NC, USA, 2017; 4p. [CrossRef]

45. Donnegan, J.A.; Mann, S.S.; Butler, S.L.; Hiserote, B.A. American Samoa's Forest Resources, 2001; Resour. Bull. PNW-RB-244; U.S. Department of Agriculture, Forest Service, Pacific Northwest Research Station: Portland, OR, USA, 2004; 32p. 
46. Donnegan, J.A.; Butler, S.L.; Kuegler, O.; Stroud, B.J.; Hiserote, B.A.; Rengulbai, K. Palau's Forest Resources, 2003; Resour. Bull. PNW-RB-252; U.S. Department of Agriculture, Forest Service, Pacific Northwest Research Station: Portland, OR, USA, 2007; 52p.

47. Gon, S.M.; Allison, A.; Cannarella, R.; Jacobi, J.D.; Kaneshiro, K.Y.; Kido, M.H.; Lane-Kamahele, M.; Miller, S.E. A Gap Analysis of Hawaii; U.S. Department of the Interior, Geological Survey, National Gap Analysis Program: Moscow, ID, USA, 2006.

48. Palau Conservation Society and The Nature Conservancy [PCS and TNC]. MC Terrestrial Measures Workshop; Palau Conservation Society and The Nature Conservancy: Chuuk, Federated States of Micronesia, 2011; Available online: https://docs.google.com/file/d/11lmEjI7CVQ_yU9tyygnE_HkTIe_ MTWMJzq1soCvwlkspxuq6DIl_rbr3MHHJ/edit?pli=1 (accessed on 12 September 2016).

49. Gould, W.A.; Alarcón, C.; Fevold, B.; Jiménez, M.E.; Martinuzzi, S.; Potts, G.; Quiñones, M.; Solórzano, M.; Ventosa, E. The Puerto Rico Gap Analysis Project Volume 1: Land cover, Vertebrate Species Distributions, and Land Stewardship; Gen. Tech. Rep. IITF-GTR-39; U.S. Department of Agriculture, Forest Service, International Institute of Tropical Forestry: Río Piedras, PR, USA, 2008.

50. Gould, W.A.; Solórzano, M.; Potts, G.U.S. Virgin Islands Gap Analysis Project. Gap Anal. Bull. 2010, 17, 35-36.

51. Acevedo-Rodríguez, P. Flora of St. John, U.S. Virgin Islands; Memoirs of the New York Botanical Garden; New York Botanical Garden: New York, NY, USA, 1996; Volume 78, pp. 1-581.

52. Eldredge, L.G.; Miller, S.E. How many species are there in Hawaii? Bish. Mus. Occas. Pap. 1995, 41, 3-18.

53. Joglar, R.L. Biodiversidad de Puerto Rico: Vertebrados Terrestres y Ecosistemas; Instituto de Cultura Puertorriqueña: San Juan, PR, USA, 2005; 563p.

54. Liogier, H.A.; Martorell, L.F. Flora of Puerto Rico and Adjacent Islands: A Systematic Sinopsis; Editorial de la Universidad de Puerto Rico: San Juan, PR, USA, 1998; 394p.

55. Mitchell, C.; Ogura, C.; Meadows, D.W.; Kane, A.; Strommer, L.; Fretz, S.; Leonard, D.; McClung, A. Hawaii's Comprehensive Wildlife Conservation Strategy; State of Hawaii, Department of Land and Natural Resources: Honolulu, HI, USA, 2005; 734p. Available online: http://dlnr.hawaii.gov/wildlife/hswap/cwcs/ (accessed on 16 September 2016).

56. Pyle, R.L.; Pyle, P. The Birds of the Hawaiian Islands: Occurrence, History, Distribution, and Status; Version 1; B.P. Bishop Museum: Honolulu, HI, USA, 2009; Available online: http://hbs.bishopmuseum.org/birds/rlpmonograph/ (accessed on 22 October 2019).

57. Riegl, B.M.; Dodge, R.E. Coral Reefs of the USA; Springer: New York, NY, USA, 2008; 803p.

58. Suárez Zapata, V. Animal wildlife. In Encyclopedia; Fundación Puertorriqueña de las Humanidades: San Juan, PR, USA, 2014; Available online: https:/enciclopediapr.org/en/encyclopedia/animal-wildlife/ (accessed on 28 June 2017).

59. Weaver, P.L. Estate Thomas Experimental Forest, St. Croix, U.S. Virgin Islands: Research History and Potential; Gen. Tech. Rep. IITF-30; U.S. Department of Agriculture, Forest Service, International Institute of Tropical Forestry: Río Piedras, PR, USA, 2006; 62p.

60. Ostertag, R.; Inman-Narahari, F.; Cordell, S.; Giardina, C.P.; Sack, L. Forest structure in low-diversity tropical forests: A study of Hawaiian wet and dry forests. PLoS ONE 2014, 9, e103268. [CrossRef]

61. Price, J.P.; Clague, D.A. How old is the Hawaiian biota? Geology and phylogeny suggest recent divergence. Proc Biol Sci. 2002, 269, 2429-2435. [CrossRef] [PubMed]

62. Ness, I. The Global Prehistory of Human Migration; John Wiley and Sons: New York, NY, USA, 2014; 458p.

63. Campbell, J. Development, global change and traditional food security in Pacific Island countries. Reg. Environ. Chang. 2014, 15, 1313-1324. [CrossRef]

64. Mascaro, J.; Hughes, R.F.; Schitzer, S.A. Novel forests maintain ecosystem processes after the decline of native tree species. Ecol. Monogr. 2012, 82, 221-228. [CrossRef]

65. Miller, G.; Lugo, A.E. Guide to the ecological systems of Puerto Rico; General Technical Report IITF-GTR-35; U.S. Department of Agriculture, Forest Service, International Institute of Tropical Forestry: Rio Piedras, PR, USA, $2008 ; 437 p$.

66. Wagner, W.L.; Herbst, D.R.; Sohmer, S. Manual of the flowering plants of Hawaii, 2nd ed.; Bishop Museum: Honolulu, HI, USA, 1999.

67. Rafaelle, H. A guide to the birds of Puerto Rico and the Virgin Islands; Fondo Educativo Interamericano: San Juan, PR, USA, 1983; 225p. 
68. Mittermeier, R.A.; Turner, W.R.; Larsen, F.W.; Brooks, T.M.; Gascon, C. Global Biodiversity Conservation: The Critical Role of Hotspots. In Biodiversity Hotspots; Zachos, F., Habel, J., Eds.; Springer: Berlin/Heidelberg, Germany, 2011.

69. Churchyard, T.; Eaton, M.A.; Havery, S.; Hall, J.; Millett, J.; Farr, A.; Cuthbert, R.J.; Stringer, C.; Vickery, J.A. The biodiversity of the United Kingdom's Overseas Territories: A stock take of species occurrence and assessment of key knowledge gaps. Biodivers. Cons. 2016, 25, 1677-1694. [CrossRef]

70. USDA Forest Service. National Report on Sustainable Forests-2010; FS-979; Robertson, G., Ed.; USDA Forest Service: Washington, DC, USA, 2011; 212p.

71. IUCN International Union for Conservation of Nature Red List of Threatened Species online database. Available online: http://www.iucnredlist.org/ (accessed on 5 August 2019).

72. USFWS. U.S. Fish and Wildlife Service Endangered Species. Available online: https://www.fws.gov/ endangered/ (accessed on 5 August 2019).

73. Walther, M. Extinct Birds of Hawaii; Mutual Publishing: Honolulu, HI, USA, 2016; 238p.

74. Pratt, T.K.; Atkinson, P.J.; Banko, P.C.; Jacobi, J.J.D.; Woodworth, B.I. Conservation Biology of Hawaiian Forest Birds: Implications for Island Avifauna; Yale University Press: New Haven, CT, USA, 2009.

75. Fritts, T.H.; Rodda, G.H. The role of introduced species in the degradation of island ecosystems: A case history of Guam. Annu. Rev. Ecol. Syst. 1998, 29, 113-140. [CrossRef]

76. Lugo, A. Estimating reductions in the diversity of tropical forest species. In Biodiversity; Wilson, E.O., Peters, F.M., Eds.; National Academy Press: Washington, DC, USA, 1988; pp. 58-70.

77. Lugo, A.E. Can we manage tropical landscapes?-An answer from the Caribbean. J. Landsc. Ecol. 2002, 17, 601-615. [CrossRef]

78. Brash, S. Avifauna Reflections of Historical Landscape Ecology in Puerto Rico; Yale University Press: New Haven, CT, USA, 1984; 40p.

79. Matsuwaki, D.H. Plantation Acreage by Island and Land Ownership Type; Unpublished Report; Department of Lands and Natural Resources, Division of Forestry and Wildlife: Honolulu, HI, USA, 2015; p. 96813.

80. Donnegan, J.; Butler, S.; Grabowiecki, W.; Hiserote, B.; Limtiaco, D. Guam's Forest Resources, 2001; Resour. Bull. PNW-RB-243; U.S. Department of Agriculture, Forest Service, Pacific Northwest Research Station: Portland, OR, USA, 2004; 32p. Available online: https://www.treesearch.fs.fed.us/pubs/7542 (accessed on 21 June 2017).

81. Donnegan, J.; Butler, S.; Kuegler, O.; Hiserote, B. Federated States of Micronesia Forest Resources, 2006; Resour. Bull. PNW-RB-262; U.S. Department of Agriculture, Forest Service, Pacific Northwest Research Station: Portland, OR, USA, 2011; 50p. Available online: https://www.treesearch.fs.fed.us/pubs/39459 (accessed on 21 June 2017).

82. Donnegan, J.; Trimble, S.; Kusto, K.; Kuegler, O.; Hiserote, B. Republic of the Marshall Islands Forest Resources, 2008; Resour. Bull. PNW-RB-263; U.S. Department of Agriculture, Forest Service, Pacific Northwest Research Station: Portland, OR, USA, 2011; 29p.

83. Donnegan, J.A.; Butler, S.L.; Kuegler, O.; Hiserote, B.A. Commonwealth of the Northern Mariana Islands Forest Resources, 2004; Resour. Bull. PNW-RB-261; U.S. Department of Agriculture, Forest Service, Pacific Northwest Research Station: Portland, OR, USA, 2011; 40p.

84. Francis, J.K. Forest plantations in Puerto Rico. In Tropical Forests: Management and Ecology; Lugo, A.E., Lowe, C., Eds.; Springer: New York, NY, USA, 1995; pp. 211-223.

85. Territory of Guam. Guam Statewide Forest Resource Assessment and Resource Strategy 2010-2015; Department of Agriculture, Forestry \& Soil Resources Division: Mangilao, Guam, 2010; 142p, + Appendices. Available online: http://www.thewflc.org/islandforestry/guam.pdf (accessed on 10 September 2016).

86. Republic of Palau. The Republic of Palau Statewide Assessment of Forest Resources and Resource Strategy-A Comprehensive Analysis of Forest Related Conditions, Trends, Threats and Opportunities; Ministry of Natural Resources, Environment \& Tourism, Bureau of Agriculture, Forestry Section: Ngerulmud, Palau, 2010; 106p.

87. Weaver, P.L.; Francis, J.K. Growth of teak, mahogany, and Spanish cedar on St. Croix, U.S. Virgin Islands. Turrialba 1988, 38, 308-317.

88. State of Hawaii. Forest Industry Development Research; State of Hawaii; Department of Land and Natural Resources: Honolulu, HI, USA, 2006. 
89. State of Hawaii. Hawaii Statewide Assessment of Forest Conditions and Trends: 2010_An Assessment of the State of our 'Aina; Hawaii Department of Land and Natural Resources, Division of Forestry and Wildlife: Honolulu, HI, USA, 2010; 271p, + Appendices. Available online: https://dlnr.hawaii.gov/forestry/files/2013/09/SWARSEntire-Assessment-and-Strategy.pdf (accessed on 2 February 2017).

90. Federated States of Micronesia (FSM). Federated States of Micronesia State-Wide Assessment and Resource Strategy 2010-2015+; Department of Resources and Development: Palikir, Pohnpei, Federated States of Micronesia, 2010; p. 215.

91. Schultz, C.J.; Nauslar, N.J.; Watcher, J.B.; Hain, C.R.; Bell, J.B. Spatial, temporal, and electrical characteristics of lightning in reported lightning-initiated wildfire events. Fire 2019, 2, 18. [CrossRef]

92. Robbins, A.M.J.; Eckelmann, C.; Quiñones, M. Forest fires in the insular Caribbean. AMBIO 2008, 37, 528-534. [CrossRef]

93. Berg, M.P.; Kiers, E.T.; Driessen, G.; van der Heijden, M.; Kooi, B.W.; Kuenen, F.; Liefting, M.; Verhoef, H.A.; Ellers, J. Adapt or disperse: Understanding species persistence in a changing world. Glob. Chang. Biol. 2010, 16, 587-598. [CrossRef]

94. Vitousek, S.; Barnard, P.L.; Fletcher, C.H.; Frazer, N.; Erikson, L.; Storlazzi, C.D. Doubling of coastal flooding frequency within decades due to sea-level rise. Sci. Rep. 2017, 7, 1399. [CrossRef] [PubMed]

95. Slangen, A.B.A.; Carson, M.; Katsman, C.A.; van de Wal, R.S.W.; Köhl, A.; Vermeersen, L.L.A.; Stammer, D. Projecting twenty-first century regional sealevel changes. Clim. Chang. 2014, 124, 317-332. [CrossRef]

96. Storlazzi, C.D.; Elias, E.P.L.; Berkowitz, P. Many atolls may be uninhabitable within decades due to climate change. Sci. Rep. 2015, 5, 14546. [CrossRef] [PubMed]

97. National Oceanic and Atmospheric Administration. Tides and Currents. Sea Level Trends. U.S. Stations: 2019. Available online: https://tidesandcurrents.noaa.gov/sltrends/sltrends_us.html (accessed on 1 October 2019).

98. Anderson, R.C.; Gardner, D.E.; Daehler, C.C.; Meinzer, F.C. Dieback of Acacia koa in Hawaii: Ecological and pathological characteristics of affected stands. For. Ecol. Manag. 2002, 162, 273. [CrossRef]

99. Nick, D.; Tyler, J.; Robert, J.; Richard, S.; Jessica, W.; Christina, L.; Gugger, P.F.; Cannon, P. Applied genetic conservation of Hawaiian Acacia koa: An eco-regional approach. In Gene Conservation of Tree Species-Banking on the Future. Proceedings of a Workshop; Gen. Tech. Rep. PNW-GTR-963; Sniezko, R.A., Man, G., Hipkins, V., Woeste, K., Gwaze, D., Kliejunas, J.T., McTeague, B.A., Eds.; U.S. Department of Agriculture, Forest Service, Pacific Northwest Research Station: Portland, OR, USA, 2017; pp. 78-91.

100. Global Invasive Species Database. Invasive Species Specialist Group of the International Union for the Conservation of Nature (IUCN) Species Survival Commission. 2011. Available online: http://www.issg.org/ (accessed on 10 September 2016).

101. Engeman, R.M.; Laborde, J.E.; Constantin, B.U.; Shwiff, S.A.; Hall, P.; Duffiney, A.; Luciano, F. The economic impacts to commercial farms from invasive monkeys in Puerto Rico. Crop Prot. 2010, 29, 401-405. [CrossRef]

102. López-Torres, A.L.; Claudio-Hernández, H.K.; Rodríguez-Gómez, C.A.; Longo, A.V.; Joglar, R.L. Green iguanas (Iguana iguana) in Puerto Rico: Is it time for management? Biol. Invasions 2011, 14, 35-45. [CrossRef]

103. Lugo, A. The outcome of alien tree invasions in Puerto Rico. Front. Ecol. Environ. 2004, 2, 265-273. [CrossRef]

104. Abelleira Martínez, O.J.; Rodríguez, M.A.; Rosario, I.; Soto, N.; López, A.; Lugo, A.E. Structure and species composition of novel forests dominated by an introduced species in northcentral Puerto Rico. New Forests. 2010, 39, 1-18. [CrossRef]

105. Francis, J.K.; Lowe, C.A.; Trabanino, S. translator. Silvics of Native and Exotic Trees of Puerto Rico and the Caribbean Islands (Spanish version); Gen. Tech. Rep. IITF-GTR-15; U.S. Department of Agriculture, Forest Service, International Institute of Tropical Forestry: Río Piedras, PR, USA, 2000; 571p.

106. Mascaro, J.; Becklund, K.K.; Hughes, R.F.; Schnitzer, S.A. Limited native plant regeneration in novel, exotic-dominated forests on Hawaii. For. Ecol. Manag. 2008, 256, 593-606. [CrossRef]

107. Hughes, R.F.; Denslow, J.S. Invasion by an N2-fixing tree, Falcataria moluccana, alters function, composition, and structure of wet lowland forests of Hawaii. Ecol. Appl. 2005, 15, 1615-1628. [CrossRef]

108. Mortenson, L.A.; Hughes, R.F.; Friday, J.B.; Keith, L.M.; Barbosa, J.M.; Friday, N.J.; Liu, Z.; Sowards, T.G. Assessing spatial distribution, stand impacts and rate of Ceratocystis fimbriata induced 'ōhi'a (Metrosideros polymorpha) mortality in a tropical wet forest, Hawaii Island, USA. For. Ecol. Manag. 2016, 377, 82-92. [CrossRef]

109. D'Antonio, C.; Vitousek, P. Biological invasions by exotic grasses, the grass-fire cycle and global change. Annu. Rev. Ecol. Syst. 1992, 23, 63-88. [CrossRef] 
110. Freifelder, R.R.; Vitousek, P.M.; D'Antonio, C.M. Microclimate change and effect on fire following forest-grass conversion in seasonally dry tropical woodland. Biotropica 1998, 30, 286-297. [CrossRef]

111. Mack, M.C.; D'Antonio, C.M.; Ley, R.E. Alteration of ecosystem nitrogen dynamics by exotic plants: A case study of C4 grasses in Hawaii. Ecol. Appl. 2001, 11, 1323-1335.

112. Litton, C.M.; Sandquist, D.R.; Cordell, S. Effects of non-native grass invasion on aboveground carbon pools and tree population structure in a tropical dry forest of Hawaii. For. Ecol. Manag. 2006, 231, 105-113. [CrossRef]

113. Cabin, R.J.; Weller, S.G.; Lorence, D.H.; Flynn, T.W.; Sakai, A.K.; Sandquist, D.; Hadway, L.J. Effects of long-term ungulate exclusion and recent alien species control on the preservation and restoration of a Hawaiian tropical dry forest. Conserv. Biol. 2000, 14, 439-453. [CrossRef]

114. Hess, S.C.; Jeffrey, J.J.; Ball, D.L.; Babich, L. Efficacy of Feral Pig Removals at Hakalau Forest National Wildlife Refuge; Tech. Report HCSU-004; University of Hawaii at Hilo, Hawaii Cooperative Studies Unit: Hilo, HI, USA, 2006; 60p.

115. March, J.G.; Benstead, J.P.; Pringle, C.M.; Scatena, F.N. Damming tropical island streams: Problems, solutions, and alternatives. BioScience 2003, 53, 1069-1078. [CrossRef]

116. Crook, K.E.; Scatena, F.N.; Pringle, C.M. Water Withdrawn from the Luquillo Experimental Forest, 2004; Gen. Tech. Rep. IITF-GTR-36; U.S. Department of Agriculture, Forest Service, International Institute of Tropical Forestry: San Juan, PR, USA, 2007; 26p.

117. Gardner, L.S. A Strategy for Management of Ghuts in the U.S. Virgin Islands; USGS Project 2007VI92B; University of the Virgin Islands, Water Resources Research Institute: St. Croix, VI, USA, 2008; 23p.

118. Heartsill-Scalley, T.; Aide, T.M. Riparian vegetation and stream condition in a tropical agriculture-secondary forest mosaic. Ecol. Appl. 2003, 13, 225-234. [CrossRef]

119. Asner, G.P.; Sousan, S.; Knapp, D.E.; Selmants, P.C.; Martin, R.E.; Hughes, R.F.; Giardina, C.P. Rapid forest carbon assessments of oceanic islands: A case study of the Hawaiian archipelago. Carbon Balance Manag. 2016, 11, 1. [CrossRef]

120. Donato, D.C.; Kauffman, J.B.; Mackenzie, R.A.; Ainsworth, A.; Pfleeger, A.Z. Whole-island carbon stocks in the tropical Pacific: Implications for mangrove conservation and upland restoration. J. Environ. Manag. 2012, 97 (Suppl. C), 89-96. [CrossRef]

121. Selmants, P.C.; Giardina, C.P.; Sousan, S.; Knapp, D.E.; Kimball, H.L.; Hawbaker, T.J.; Morena, A.; Seirer, J.; Running, S.W.; Miura, T.; et al. Chapter 6. Baseline Carbon Storage and Carbon Fluxes in Terrestrial Ecosystems of Hawaii. In Baseline and Projected Future Carbon Storage and Carbon Fluxes in Ecosystems of Hawaii; U.S. Geological Survey Professional Paper 1834; Selmants, P.C., Giardina, C.P., Jacobi, J.D., Zhu, Z., Eds.; U.S. Geological Survey: Washington, DC, USA, 2017. Available online: https://pubs.usgs.gov/pp/1834/a/pp1834_ chapter6.pdf (accessed on 8 October 2019).

122. American Samoa Community College. American Samoa Forest Assessment and Resource Strategy 2011-2015; Division of Community and Natural Resources, Forestry Program: Pago Pago, AS, USA, 2010; 62p. Available online: http://www.thewflc.org/islandforestry/americansamoa.pdf (accessed on 9 September 2016).

123. Commonwealth of the Northern Mariana Islands. Commonwealth of the Northern Mariana Islands (CNMI) Statewide Assessment and Resource Strategy 2010-2015+; Department of Lands and Natural Resources: Saipan, Commonwealth of Northern Mariana Islands, 2010; 77p. Available online: http://www.thewflc.org/ islandforestry/cnmi.pdf (accessed on 9 September 2016).

124. Government of Puerto Rico. Puerto Rico Statewide Assessment and Strategies for Forest Resources; Department of Natural and Environmental Resources: San Juan, PR, USA, 2010; 100p. Available online: http://www. stateforesters.org/files/PuertoRico-PR201010221856-001.pdf (accessed on 9 September 2016).

125. Republic of the Marshall Islands. Republic of the Marshall Islands "State"-Wide Assessment and Resource Strategy 2010-2015+; Ministry of Resources and Development: Majuro, Republic of the Marshall Islands, 2010; 63p. Available online: http://www.thewflc.org/islandforestry/marshalls.pdf (accessed on 9 September 2016).

126. U.S. Virgin Islands. U.S. Virgin Islands Forest Resources Assessment and Strategies: A Comprehensive Analysis of Forest-Related Conditions, Trends, Threats, and Strategies; Department of Agriculture, Forestry Division: Kingshill, VI, USA, 2010; 96p. Available online: http://geographicconsulting.com/wp-content/uploads/2011/05/USVIForest-Resources-Assessmentand-Strategies-2-sideds-printing-VIDOA.pdf (accessed on 9 September 2016). 
127. Chamberlain James, L.; Emery Marla, R.; Patel-Weynand, T. Assessment of Nontimber Forest Products in the United States under Changing Conditions; Gen. Tech. Rep. SRS-232; U.S. Department of Agriculture, Forest Service, Southern Research Station: Asheville, NC, USA, 2018.

128. Asian Development Bank. Juumemmej: Republic of the Marshall Islands Social and Economic Report 2005; ADB Pacific Studies Series: Manila, Philippines, 2005; 169p.

129. Drew, W.M.; Ewel, K.C.; Naylor, R.L.; Sigrah, A. A tropical freshwater wetland: III. Direct use values and other goods and services. Wetl. Ecol. Manag. 2005, 13, 685-693. [CrossRef]

130. Naylor, R.; Drew, M. Valuing mangrove resources in Kosrae, Micronesia. Environment and Development. Economics 1998, 3, 471-490.

131. Hobbs, R.J. Grieving for the past and hoping for the future: Balancing polarizing perspectives in conservation and restoration. Restor. Ecol. 2013, 21, 145-148. [CrossRef]

132. Hobbs, R.J.; Higgs, E.; Hall, C.M.; Bridgewater, P.; Chapin, F.S., III; Ellis, E.C.; Ewel, J.J.; Hallett, L.M.; Harris, J.; Hulvey, K.B.; et al. Managing the whole landscape: Historical, hybrid, and novel ecosystems. Front. Ecol. Environ. 2014, 12, 557-564. [CrossRef]

133. Murcia, C.; Aronson, J.; Kattan, G.H.; Moreno-Mateos, D.; Dixon, K.; Simberloff, D. A critique of the 'novel ecosystem' concept. Trends Ecol. Evol. 2014, 29, 548-553. [CrossRef] [PubMed]

(C) 2019 by the authors. Licensee MDPI, Basel, Switzerland. This article is an open access article distributed under the terms and conditions of the Creative Commons Attribution (CC BY) license (http://creativecommons.org/licenses/by/4.0/). 